FEDERAL RESERVE BANK OF SAN FRANCISCO

WORKING PAPER SERIES

\title{
The Labor Market in the Great Recession
}

\author{
MICHAEL ELSBY \\ University of Michigan and NBER \\ BART HOBIJN \\ Federal Reserve Bank of San Francisco and Free University Amsterdam \\ AYŞEGÜL ŞAHIN \\ Federal Reserve Bank of New York \\ March 2010 \\ Working Paper 2010-07 \\ http://www.frbsf.org/publications/economics/papers/2010/wp10-07bk.pdf
}

The views in this paper are solely the responsibility of the authors and should not be interpreted as reflecting the views of the Federal Reserve Bank of San Francisco or the Board of Governors of the Federal Reserve System. 
MICHAEL ELSBY

University of Michigan and NBER

BART HOBIJN

Federal Reserve Bank of San Francisco and Free University Amsterdam

AYŞEGÜL ŞAHINN

Federal Reserve Bank of New York ${ }^{*}$

\section{The Labor Market in the Great Recession}

Prepared for Brookings Panel on Economic Activity, March 18-19, 2010. This version: March $8^{\text {th }} 2010$.

\footnotetext{
* The views expressed in this paper solely reflect those of the authors and not necessarily those of the Federal Reserve Bank of New York, Federal Reserve Bank of San Francisco, nor those of the Federal Reserve System as a whole. We are especially grateful to Bruce Fallick, Larry Katz, Ryan Michaels, David Romer, Gary Solon, and Justin Wolfers for particularly detailed comments and suggestions. Thanks also to Mary Daly, Steve Davis, Hank Farber, Bob Hall, John Haltiwanger, Marianna Kudlyak, Simon Potter, and Jon Willis for constructive comments. We would like to thank Regis Barnichon for providing us with the Composite HelpWanted Index, and Joyce Kwok, Joseph Song, and Theodore Wiles for their outstanding research assistance. This version is based on data through February $15^{\text {th }} 2010$.
} 
Since December 2007, labor market conditions in the United States have deteriorated dramatically. The depth and duration of the decline in economic activity have led many to refer to the downturn as the Great Recession. In this paper, we document the adjustment of the labor market during the recession, and place it in the broader context of previous postwar downturns. What emerges is a picture of labor market dynamics with three key recurring themes:

1. From the perspective of a wide range of labor market outcomes, the 2007 recession represents the deepest downturn in the labor market in the postwar era.

2. Until recently, the nature of labor market adjustment in the current recession has displayed a notable resemblance to that observed in past severe downturns.

3. During the latter half of 2009, however, the path of adjustment has exhibited important departures from that seen in prior deep recessions.

These broad conclusions arise from a detailed investigation of the behavior of labor market stocks and flows over the course of the downturn. Our point of departure in section 1 is to document the evolution of key labor market indicators - unemployment, employment, labor force participation, and hours - during the recession. No matter what indicator of labor market activity we consider, the deterioration of labor market conditions during the 2007 recession is the worst on record since the late 1940s. Rates of unemployment among all the major subgroups of the labor market have reached postwar highs. From the perspective of the labor market, the 2007 recession is truly a Great Recession.

As noted above, we nonetheless observe that many dimensions of the evolution of these key indicators mirror those seen in past recessions. Labor force participation has declined, reflecting the modest procyclicality observed in many postwar recessions; the relative contributions of the intensive and extensive margins to the decline in total labor input typify the conventional one third hours to two thirds bodies split observed in the past; and the constellation of demographic groups most affected-young, male, less-educated, workers from ethnic minorities - is reminiscent of previous downturns.

It is well-known that changes in aggregate unemployment in the United States mask substantial variation in underlying worker flows, a point emphasized by Blanchard and Diamond (1990). Reflecting this, in section 2 we investigate the sources of increased unemployment by analyzing the 
behavior of unemployment flows. This reveals that both increased unemployment inflows as well as declines in the rate at which workers flow out of the unemployment pool play crucial roles in accounting for the recent upswing in unemployment. As in previous severe recessions, the initial ramp-up in unemployment was accompanied by a sharp rise in inflows. In contrast to the claims of recent literature on unemployment flows (Hall, 2005; Shimer, 2007), elevated rates of inflow in times of recession appear not to be a relic of past downturns, but rather a distinctive feature of severe recessions, both old and modern. The behavior of the outflow rate also mirrors that observed in past deep recessions: As the wave of inflows has receded in the latter stages of the current recession, the outflow rate has continued to fall. Reflecting the distinctive severity of the downturn, recent data has seen the outflow rate reach a postwar low.

Measures of unemployment flows among labor force groups yield an important message on the sources of disparate trends in unemployment across labor force groups: Greater levels and cyclical sensitivity of joblessness among young, low-skilled minority workers, both in this and in previous downturns, are driven predominantly by differences in rates of entry into unemployment across these groups. In sharp contrast, a striking feature of unemployment exit rates is a remarkable uniformity in their cyclical behavior across labor force groups - the declines in outflow rates during this and prior recessions are truly an aggregate phenomenon.

In the remainder of section 2 , we take advantage of a unique opportunity to assess the role of labor turnover in the recession. This is the first full upswing in unemployment covered by the new Job Openings and Labor Turnover Survey (JOLTS), which reveals some stark findings. In contrast to the behavior of unemployment inflows, rates of separation of workers from employers have not risen in the 2007 recession. This is suggestive of a hypothesis noted by Hall (2005): increases in unemployment inflows may have little to do with increased rates of job loss, but merely are a symptom of declining rates of job finding among potential job-to-job movers. Our analysis of JOLTS data points to a different story: Increased inflows into unemployment are driven predominantly by a change in the composition of separations toward layoffs, which are likely to result in unemployment, and away from quits, which most often involve people who flow to a new job upon separation. Job loss has played a key role in driving increased unemployment in the recession. 
We close our analysis in section 3 with an assessment of the outlook for the recovery of the labor market in the wake of the current downturn. Motivated by the recent subsidence of inflows into unemployment and the historic declines in the exit rate from unemployment, we emphasize the importance of a rebound in the outflow rate for future reductions in unemployment and highlight a potential cause for concern that has developed in recent data. The postwar U.S. labor market has been characterized by two remarkably stable aggregate relationships: the negative comovement of unemployment and vacancies - the Beveridge curve-and the positive association between the outflow rate from unemployment and the vacancy-unemployment ratio, a point noted by Shimer (2005). The latter half of 2009 has witnessed a break from these relations, with unemployment rising higher than implied by the historical Beveridge curve, and the outflow rate from unemployment falling significantly below the path implied by the past relation with the vacancyunemployment ratio.

The resemblance of these trends to the similar breakdown in match efficiency that accompanied the European unemployment problem of the 1980s raises the concern of persistent unemployment, or hysteresis, in U.S. unemployment going forward. We consider a range of possible sources that might lead to hysteresis, including sectoral mismatch, extension of unemployment insurance (UI) benefits, duration dependence in unemployment outflow rates, and persistence in unemployment brought about by reductions in the rate of worker flows, what Blanchard (2000) has termed sclerosis. Recent data point to two warning signs going forward. First, the historic decline in unemployment outflow rates has been accompanied by a record rise in long-term unemployment. We show that this is likely to result in a persistent residue of long-term unemployed workers with relatively weak search effectiveness, depressing the strength of the recovery. Second, conventional estimates of the impact of UI duration on the length of unemployment spells suggest that the extension of Emergency Unemployment Compensation starting in June 2008 is likely to have led to a modest increase in long-term unemployment in the recession. Nonetheless, we conclude that, despite these adverse forces, they have not yet reached a magnitude that would augur a Europeanstyle hysteresis problem in the U.S. economy in the long run. 


\section{Basic Facts about the Labor Market in the 2007 Recession}

The recession that started in December 2007 has been severe according to many measures, not least in terms of its effect on the labor market. In this section, we review the recent behavior of some of the main aggregate measures of labor market outcomes, and place the deterioration in labor market conditions of the current downturn in the broader historical context of previous postwar recessions.

\subsection{Unemployment, Employment, Labor Force Participation and Hours}

The main labor market indicator that we will focus on for much of this paper is the unemployment rate. To set the stage, Figure 1 displays the published time series for the civilian unemployment rate from Current Population Survey (CPS) data. The current recession is a very prominent feature of this series. Unemployment rose from a pre-recession minimum of 4.4 percent to reach 10.1 percent in October 2009. This increase-5.7 percentage points-is the largest postwar upswing in the unemployment rate. It dwarfs the rise in joblessness in the two most recent recessions in 1990 and 2001, when in each case unemployment rose by approximately 2.5 percentage points. It dominates even the severe recession of 1973/4 (4.25 percentage points) as well as the combined effects of the double recession of the early 1980s (5 percentage points). There is little doubt that the present downturn is the deepest postwar recession from the perspective of the labor market. ${ }^{1}$

In what follows, we will closely examine the rise in unemployment in the present downturn. But it is helpful at this point to place the increase in joblessness in the broader context of other related labor market indicators. We consider two sets of measures: First, the relation between the rise in unemployment and the decline in employment during the downturn; and second, the role of declines in employment relative to hours per worker in accounting for the contraction in total labor input.

The decline in employment. The unemployment rate at a given point in time $u_{t}$ can be related to the level of employment $E_{t}$, and the labor force $L_{t}$, via the simple identity $u_{t}=1-\left(E_{t} / L_{t}\right)$. This identity suggests a simple metric for gauging the relative roles of variation in employment and labor force participation in accounting for the upswing in unemployment, since

\footnotetext{
${ }^{1}$ While the current Great Recession is the most severe postwar recession, it is important to note that, as is true of all recent recessions, the current ramp-up in the unemployment rate is dwarfed by that witnessed during the Great Depression: In 1929, the unemployment rate stood at 3.2 percent, rising to 25.2 percent by 1933, a 22 percentage point rise in four years. Indeed, such is the extremity of the Great Depression that adding it to any plot renders the postwar variation in joblessness very difficult to perceive.
} 


$$
d u_{t}=\left(1-u_{t}\right)\left[d \log \left(L_{t} / P_{t}\right)-d \log \left(E_{t} / P_{t}\right)\right]
$$

where $P_{t}$ denotes the working-age population. The increase in the unemployment rate over the course of a recession can be decomposed into parts accounted for by logarithmic variation in the labor force participation rate and the employment-population ratio respectively.

This exercise is performed in Figure 2. It plots the cumulative log deviations from trend of the published time series for the employment-population ratio and the labor force participation rate from the CPS for the last six recessions. Figure 2 has two related messages. First, the record upswing in the unemployment rate observed in Figure 1 is mirrored by a record contraction in employment: Employment has declined relative to trend by $7 \log$ points since the start of the recession, dominating the severe recession of the mid 1970s, as well as the joint effects of the double recession of the early 1980 s.

A second message of Figure 2 is that, rather than contributing to the rise in unemployment, a reduction in labor force participation of around $2 \log$ points has muted the rise in joblessness in the current recession. Figure 2 also reveals that the current recession is no exception in this respect: Almost all of the downturns prior to 2007 also exhibit a mild procyclicality of labor force participation.

An interesting aspect of the response of labor force participation in this recession is that it seems to have had two stages. Daly, Hobijn, and Kwok (2009a) emphasize that during the first part of the recession the labor force participation rate remained unexpectedly high. Since May 2009, however, the labor force participation rate fell by 1.7 percentage points, its steepest decline since the 1950s.

Unemployment and GDP (Okun's Law). One of the most robust aggregate statistical relationships for the U.S. economy is the negative comovement between changes in the unemployment rate and growth in GDP-Okun's (1962) Law. Figure 3 displays a version of Okun's Law updated to include the current recession. It plots the deviation from trend of the unemployment rate against the percentage deviation from trend of GDP using the CBO's estimates of the NAIRU and potential output up to January 2010. ${ }^{2}$ The dashed line is the regression line based on the observations from 1949 through 2007, excluding the Great Recession. In the absence of large movements in potential output and the NAIRU, Okun's Law implies that for every 2 percent that output falls below trend, the unemployment rate will increase by about 1 percentage point.

\footnotetext{
${ }^{2}$ Detrended unemployment and output data based on Hodrick-Prescott filtered series yield very similar results.
} 
This rule of thumb has performed remarkably well in accounting for the evolution of Okun's Law in the first part of the 2007 recession through 2009Q1, as indicated by the bold squares in Figure 3. Thus, as we have noted of other dimensions of the 2007 downturn, the adjustment of the labor market until the second quarter of 2009 is by no means an outlier relative to past recessions.

The last nine months of 2009, however, have witnessed an important departure from the historical path of Okun's Law: Even though overall economic activity, as measured by GDP, rebounded in the second half of 2009, the unemployment rate continued to rise. This recent divergence between output and the labor market can be traced to the high level of average labor productivity growth during that period, resulting in an increase in the unemployment rate in 2009 that surprised policymakers and forecasters alike. ${ }^{3}$ The exceptionally strong productivity growth during the onset of the recovery also occurred during the jobless recoveries that followed the previous two recessions. We revisit the implications of this for the outlook in section $3 .^{4}$

Hours vs. bodies. The evidence presented thus far has pertained solely to measures of the number of persons in or out of work, and not to the number of hours worked per employed person. Here we summarize the behavior of each of these measures, and identify their relative importance in driving the contraction in total labor input during the current downturn. Our point of departure is another simple accounting identity, namely that total labor input $H_{t}$ is the product of employment $E_{t}$ and hours per worker $h_{t}$. It follows that the logarithmic decline in total hours worked during the recession may be decomposed into the sum of the respective logarithmic declines in $E_{t}$ and $h_{t}$.

Figure 4 performs this simple accounting exercise using data on employment and weekly hours per worker in the nonfarm business sector from the Bureau of Labor Statistics' Labor Productivity and Costs program. ${ }^{5}$ It plots the cumulative log declines in employment and hours per worker for each postwar recessionary downturn in total labor input. ${ }^{6}$ Total labor input has declined by $10 \log$ points in the current recession, again more than in any other postwar recession.

\footnotetext{
${ }^{3}$ For a detailed analysis of the recent behavior of Okun's Law, see Gordon (2010).

${ }^{4}$ Nalewaik (2010) suggests that deviations from Okun's Law are less severe when one considers Gross Domestic Income, i.e. an income-based measure of output, rather than GDP, which is based on the expenditure side of the national accounts.

${ }^{5}$ The BLS series identifiers used for employment and weekly hours per worker are respectively PRS85006013 and PRS85006023. In constructing these series, the BLS combines data from the Current Employment Statistics and the CPS. Employment here includes both payroll employees as well as self-employed and unpaid family workers.

${ }^{6}$ The recession dates used for constructing Figure 4 differ slightly from the official NBER recession dates. They correspond to the quarters around the NBER recession dates over which total hours worked are observed to decline.
} 
An interesting aspect of Figure 4 is that, while the 2007 recession is unusual in its severity, the adjustment of the labor market bears an important resemblance to that observed in prior recessions. Figure 4 highlights this on two dimensions. First, we observe that reductions in hours per worker prevail in the early stages of the recession, with contractions in employment becoming dominant later on. Second, Figure 4 reiterates the message of Figure 2 that employment has fallen by $7 \log$ points, but additionally reveals that hours per worker have contracted by $3 \log$ points. Thus, there has been something close to a 70:30 bodies/hours split to the decline in total labor input over the course of the 2007 recession. This is in line with the conventional wisdom, since at least Okun (1962), that around two-thirds of the cyclical variation in labor input is accounted for by the extensive margin. Reiterating this point, Figure 4 reveals that, across the last six recessions, variation in employment accounts for between 50 and 80 percent of declines in total hours.

\subsection{Who has been hit hardest?}

Underlying the acute surge in joblessness documented in Figures 1 through 4 is a rich degree of heterogeneity in the structure of unemployment across different groups of the labor force. Here we document this heterogeneity in the experience of unemployment across groups in the labor force, focusing on four dimensions of heterogeneity: gender, age, race and educational attainment.

To assess the quantitative importance of these differences, Table 1 reports the ratio of the rise in each group's unemployment rate to the rise in the overall unemployment rate for the last five downturns using data from the CPS. If the rise in unemployment were spread uniformly across different subgroups of the labor market, the ratios in Table 1 would all equal 1 . We find that male, younger, less educated workers, as well as individuals from ethnic minorities, experience steeper rises in joblessness during all recessions, including the most recent one. ${ }^{7}$

An interesting aspect of the results in Table 1 is that the current recession is by no means an exception in terms of its gender bias. While many commentators on the present downturn have emphasized its character as a mancession, Table 1 reveals in contrast that all recessions have affected male workers disproportionately more; the mancession is not a new phenomenon. Şahin, Song, and Hobijn (2009) show that this can be traced to the fact that industries in which male

\footnotetext{
${ }^{7}$ This echoes the findings of an abundant literature that has documented differences in the cyclical sensitivity of different demographic groups (see Clark and Summers, 1981, Gomme, Rogerson, Rupert, and Wright, 2004, Kydland, 1984, Mincer 1991, for example).
} 
workers are concentrated, such as construction and durable goods manufacturing, are particularly sensitive to the cycle.

\subsection{Accounting for the Composition of the Labor Force}

Heterogeneity in the experience of unemployment across labor force groups is an important characteristic of joblessness in the current recession. Recent decades have witnessed dramatic changes in the composition of the labor force. We focus here on one particular dimension of composition that has a crucial bearing on historical comparisons of unemployment rates: age structure. The labor force has become older since the 1980s as the baby boom generation has aged, a point emphasized by Shimer $(1998,2001) .{ }^{8}$ Accounting for such compositional changes can paint a different picture of aggregate unemployment trends because these different labor force groups are systematically more or less likely to experience spells of unemployment.

We implement a simple method for controlling for the impact of changes in the age composition of the labor force on trends in aggregate unemployment, by fixing the labor force shares for each age group to their level at some reference date, and tracing out the implied composition-adjusted unemployment series. Figure 5 performs this exercise using the most recent labor force shares to construct composition-adjusted series. This reveals an interesting finding: Accounting for changes in the age composition of the labor force leads to a substantial downward revision of past unemployment rates. Figure 5 reveals that the age-adjusted unemployment rate has reached its highest level in the postwar period.

\footnotetext{
${ }^{8}$ An online appendix that accompanies this paper presents composition adjustments for the full interaction of age, gender, race and education, as well as for each dimension individually. While changing gender composition has had very little impact, composition by race and education plays a role. The influx of immigrants since the 1970s that has led to a greater fraction of Hispanic workers in the labor force, who in turn are more likely to experience an unemployment spell. On the other hand, increased educational attainment since the 1980s has shifted the structure of the labor force toward better educated workers who face lower unemployment rates on average (see Farber and Western, 2010, for more on this). Shimer (1998) cautions against adjustments for educational composition, however. Workers with higher unobserved ability are likely to face lower unemployment rates conditional on education. As workers become more educated over time, the average ability of each education group will decline, leading to an increase in that group's unemployment rate. In addition, if the educational distribution shifts, employers may simply revise the educational requirements of jobs, leading to no real effect on the unemployment rate.
} 


\section{Labor market flows in the recession}

Another defining characteristic of the U.S. labor market is that it is in a state of continual flux. Even when the aggregate economy is in a tranquil state, many workers flow in and out of employment and unemployment. In times of recession, these flows come into focus as proximate determinants of increases in joblessness: Does unemployment rise as a result of increased inflows as workers lose their jobs? Or does it rise because unemployed workers increasingly fail to find new jobs? Or is it some combination of the two?

Based on the shallow downturns of 1990 and 2001, recent research has argued that the nature of labor market adjustment in times of recession has radically shifted in recent years. Hall (2005) states that "In the modern U.S. economy, recessions do not begin with a burst of layoffs." Echoing this, in his study of unemployment flows, Shimer (2007) concludes that "Fluctuations in the employment exit probability are quantitatively irrelevant during the last two decades." 9 Instead, increased unemployment duration, or a decline in the rate at which workers flow out of the unemployment pool, is argued to drive the entirety of contemporary unemployment variation.

In contrast, a long line of research on labor market flows prior to the last two recessions came to the conclusion that cyclical ramp-ups in unemployment are driven by both margins. ${ }^{10}$ More recent work has revived this conclusion, and identified a clear pattern to unemployment flows in times of recession: Increases in unemployment are preceded by sharp rises in unemployment inflows, followed by more prolonged periods of elevated unemployment duration. ${ }^{11}$ The conclusion of that literature pointed towards cyclical ramp-ups in unemployment being driven by both margins, with inflows being relatively more dominant early on in recessions.

The current downturn provides an opportunity to assess these conclusions: Is a diminished role of job loss a feature of modern recessions, or of shallow recessions? To get a sense for this, we explore updated estimates of unemployment transitions from a variety of data sources.

\footnotetext{
${ }^{9}$ Shimer (2007) uses the term "employment exit probability" to refer to the probability of entering unemployment. We do not use this terminology because employment exit can be taken to mean a flow from employment to either unemployment or nonparticipation, of which the latter does not involve an inflow into unemployment, and may even be taken to mean any separation from employment, which would also include job-to-job flows.

${ }^{10}$ See, among others, Perry (1972), Marston (1976), Blanchard and Diamond (1990), and Baker (1992).

${ }^{11}$ See, Braun, De Bock, and DiCecio (2006); Davis (2006); Elsby, Michaels, and Solon (2009); Fujita and Ramey (2009); Kennan (2006); and Yashiv (2008).
} 


\subsection{The Ins and Outs of Unemployment in the Current Recession}

A first glimpse of the dynamics of unemployment flows can be obtained from published time series from the CPS. ${ }^{12}$ Shimer (2007) describes a method that uses monthly series on the number employed, the number unemployed, and the number unemployed for fewer than five weeks to infer the rates at which workers enter unemployment, and unemployed workers exit unemployment. His point of departure is the following description of the evolution of the unemployment stock $U_{t}$ :

$$
d U / d t=s_{t}\left(L_{t}-U_{t}\right)-f_{t} U_{t}
$$

where $s_{t}$ and $f_{t}$ are respectively the inflow and outflow rates, $L_{t}$ is the labor force, and $t$ indexes months. ${ }^{13}$

The goal of the analysis is to relate variation in the unemployment rate $u_{t}=U_{t} / L_{t}$ to variation in the flow hazards $s_{t}$ and $f_{t}$. To that end, we first need to estimate these flow rates. Following Shimer (2007), we compute the monthly outflow probability,

$$
F_{t}=1-\left[\left(U_{t+1}-U_{t+1}^{<1}\right) / U_{t}\right]
$$

where $U_{t+1}^{<1}$ is the stock of workers who report having been unemployed for less than one month. ${ }^{14}$ Intuitively, the term inside the brackets is the fraction of the unemployed in month $t$ that remains unemployed the next month, the complement of which is the monthly outflow probability. This can then be mapped into a Poisson outflow hazard rate $f_{t}=-\log \left(1-F_{t}\right)$.

Obtaining an estimate of the inflow rate is slightly more involved. Assuming that the flow hazards, $s_{t}$ and $f_{t}$, and the labor force, $L_{t}$, are constant between surveys, one can solve equation (1) forward one month to obtain:

$$
U_{t+1}=\lambda_{t} U_{t}^{*}+\left(1-\lambda_{t}\right) U_{t}
$$

\footnotetext{
${ }^{12}$ Throughout the remainder of this section we focus on unemployment flows estimated from CPS time series, rather than the longitudinally-matched monthly CPS microdata (the so-called "gross flows" data). This choice is informed by the fact that there are important measurement issues that accompany the use of the gross flows data, including spurious transitions driven by measurement error in reported labor market states in consecutive monthly surveys, non-random attrition from the sample, and discrepancies between published changes in aggregate labor market stocks and those implied by the gross flows.

${ }^{13}$ An implicit assumption underlying equation (2) is that all inflows into unemployment originate from employment, $L_{t}-U_{t}$. In fact, as we will see in what follows, a substantial fraction of inflows originate from nonparticipation in the U.S. We relax this simplifying assumption in section 2.3 below.

${ }^{14}$ As noted by Polivka and Miller (1998) and Abraham and Shimer (2001), the published time series on short term unemployment from the BLS displays a discontinuous decline following the CPS redesign in 1994, as a result of a change in the way unemployment duration was recorded. We correct the published post redesign series for short term unemployment by rescaling it by a factor of 1.16. See Elsby, Michaels, and Solon (2009) for more detail.
} 
Here unemployment is a weighted average of the flow steady state level of unemployment $U_{t}^{*}=$ $s_{t} L_{t} /\left(s_{t}+f_{t}\right)$ and last month's unemployment $U_{t}$, with weight given by the monthly rate of convergence to steady state, $\lambda_{t}=1-e^{-\left(s_{t}+f_{t}\right)}$. Since we observe the labor force and unemployment stocks in each month, and with an estimate of the outflow rate $f_{t}$ in hand, equation (4) is a nonlinear equation that can be solved for the inflow rate $s_{t}$. As emphasized by Shimer (2007), this procedure for estimating $s_{t}$ implicitly corrects for a time aggregation bias arising from inflows within a given month exiting prior to the next month's survey.

Figure 6 plots quarterly averages of the estimated monthly time series for the rates of inflow to and outflow from unemployment, using the most recent CPS data up to 2009 Q4. Figure 6 highlights a number of interesting properties of the dynamics of unemployment flows in past recessions. First, as emphasized in the entirety of research on unemployment flows, both old and new, the outflow rate from unemployment is markedly procyclical, exhibiting systematic and prolonged downswings in all recessions. Second, the inflow rate into unemployment is countercyclical, exhibiting sharp upswings at the onset of all recessions that tend to subside quickly by the end of the recession. Third, the response of unemployment inflows in the relatively mild recessions that began in 1990 and 2001 appears to be muted in comparison to other episodes, a point that echoes the recent conclusions of Hall $(2005,2007)$ and Shimer (2007).

At this point, we can return to the question that motivated this part of our analysis: To what extent is the cyclical ramp up in unemployment accounted for by changes in these flow hazard rates? Elsby, Michaels and Solon (2009) provide a simple method for answering this question. Their starting point is an observation that has been noted by many analysts of U.S. unemployment flows: That the unemployment rate in the U.S. is very closely approximated by its flow steady state value, that is

$$
u_{t} \equiv U_{t} / L_{t} \approx u_{t}^{*} \equiv s_{t} /\left(s_{t}+f_{t}\right)^{15}
$$

Equation (5) is useful for our purposes because it provides a link between variation in the unemployment stock and variation in the constituent flow hazard rates. Elsby, Michaels and Solon (2009) show that simple log differentiation of this approximate relation implies:

\footnotetext{
${ }^{15}$ To see why this is so, note that the sum of the inflow and outflow rates $s_{t}+f_{t}$ typically exceeds 0.5 on a monthly basis in the U.S An implication is that the rate of convergence to flow steady state $\lambda_{t}$ in equation (5) above tends to be very high in practice.
} 


$$
\Delta u_{t} \approx \beta_{t-1}\left[\Delta \log s_{t}-\Delta \log f_{t}\right], \text { where } \beta_{t-1}=u_{t-1}\left(1-u_{t-1}\right) .
$$

Equation (6) has a simple message: To compare changes in inflow and outflow rates on an equal footing with respect to changes in unemployment, all one needs do is compare the logarithmic variation in each of the flow hazards.

The results from applying this decomposition of unemployment variation for each recession since 1973 are depicted in Figure 7. We identify start and end dates for each recessionary ramp-up in unemployment since 1973, and compute the cumulative logarithmic difference in inflow and outflow rates relative to their respective start of recession values. In many ways, the message of Figure 7 confirms the qualitative picture suggested in Figure 6: In all recessions, inflows account for a substantial fraction of unemployment variation early on in the downturn, and then subside in the latter stages of the recession. In contrast, the contribution of the outflow rate becomes more dominant as each recession progresses.

For our current focus, there are two noteworthy aspects of Figures 6 and 7. First, mirroring the conclusions of Section 1 on labor market stocks, the behavior of unemployment flows in the initial stages of the current downturn bears a striking resemblance to the dynamics of unemployment flows in past severe recessions. The early quarters of the current ramp-up in unemployment are characterized by a wave of inflows that has since receded partially. The contribution of the inflow rate is almost identical to that observed in the 1974 downturn. Thus, returning to the question that motivated this analysis, sharp spikes in the rate of inflow into unemployment appear to be a feature of severe recessions, rather than of old ones.

Figures 6 and 7 also shed light on what's new about the current downturn. Figure 6 reveals that the unemployment outflow rate fell to an historic low of 24 percent in 2009 Q3. This is not just a consequence of the secular trend toward declining outflow hazards shown in Figure 6: Figure 7 shows that the exit rate fell by over $80 \log$ points in the current downturn, more than in any of its postwar counterparts, echoing the conclusion of Section 1 that this is the deepest postwar downturn in labor market outcomes. We return to this phenomenon in Section 3, when we discuss its implications for a recovery. 


\subsection{Unemployment Flows by Labor Force Group}

In Section 1.2 we saw that changes in unemployment rates have differed substantially across different demographic groups during the 2007 recession, with some groups being hit harder by the downturn than others. We now look into the sources of this heterogeneity by examining unemployment flows across groups.

We focus on the same four dimensions of heterogeneity as in Section 1.2. Estimation of the flow hazards for each labor force group mirrors the aggregate analysis above. ${ }^{16}$ Figure 8 displays the series for the inflow and outflow hazards for each group. They are plotted as twelve-month moving averages to smooth out noise induced by the greater sampling variance that accompanies these more disaggregated series. In accordance with the message of equation (5), the flow hazards are drawn on $\log$ scales.

Figure 8 has a rich set of implications for the structure of joblessness across groups. Perhaps its most prominent feature is the remarkable uniformity in both the levels and cyclical behavior of outflow rates across groups. Most striking are the series by education group, for which the exit rates are virtually indistinguishable since $1976 .{ }^{17}$ In the current recession, the log decline in outflow hazards has been almost identical across groups. Reductions in the outflow rate that accompany recessions, from both a qualitative and a quantitative perspective, are truly an aggregate phenomenon.

In stark contrast, there are large differences in rates of inflow into unemployment across groups. Comparison of these with the heterogeneity of unemployment across groups in Table 1 reveals a close link: The same groups that face high unemployment rates-young workers, less-educated workers, and workers from ethnic minorities - also face markedly high rates of entry into unemployment. The message of this comparison is that the bulk of the large differences in the level of unemployment across groups observed in Table 1 are driven by differences in each group's propensity to enter unemployment, rather than differences in the duration of their spells.

\footnotetext{
${ }^{16}$ The Bureau of Labor Statistics publishes seasonally unadjusted estimates of unemployment by duration starting from the mid 1970s by gender, age and race. As in Section 1.2 above, for education groups we use CPS monthly microdata files from January 1976 on to construct measures of unemployed less than five weeks, unemployed and employed by education groups. We then seasonally adjust the raw data using the Census' X12 procedure, and compute the monthly outflow and inflow rates using the analogues to equations (3) and (4) that hold for each group. As before, we also correct for discontinuities in the series for shortterm unemployment by group induced by the redesign of the CPS in 1994.

${ }^{17}$ This finding echoes the findings of Mincer (1991).
} 
In addition to revealing large differences in the levels of unemployment across groups, Table 1 also demonstrated that some groups face greater increases in unemployment in times of recession. What can account for this? Well, recalling equation (5) above, we can write the change in group $j$ 's unemployment rate as

$$
\Delta u_{j, t} \approx \beta_{j, t-1}\left[\Delta \log s_{j, t}-\Delta \log f_{j, t}\right], \text { where } \beta_{j, t-1}=u_{j, t-1}\left(1-u_{j, t-1}\right) .
$$

One possibility, then, is that these groups simply faced larger logarithmic changes in their constituent flow hazards. Inspection of Figure 8 reveals that this is precisely what accounts for the surge in the unemployment of men relative to women in the current recession: While male and female outflow rates have been essentially identical, men have faced a much larger increase in inflows, a point emphasized by Şahin, Song, and Hobijn (2009). ${ }^{18}$

But this is not the whole story. For age, race and education groups, there is little difference in the cyclicality of unemployment flows, and whatever differences exist tend to predict the opposite of the pattern depicted in Table 1. For example, outflow rates among young workers aged 16 to 24 have fallen just as much as for older workers, and their inflow rates have hardly risen in the recession. Yet, in Table 1, the unemployment rate among 16 to 24 year-olds rose substantially more than aggregate unemployment.

The answer lies in equation (7) above: For values of the group-specific unemployment rates $u_{j, t}$ observed in Table 1 (i.e. lying below one half), $\beta_{j, t-1}$ is increasing in $u_{j, t-1}$. Thus, the higher the unemployment rate faced by an individual group, the greater the responsiveness of the group's unemployment rate to changes in its constituent flow hazards. Intuitively, equation (7) implies that changes in the flow hazards have a logarithmic influence on unemployment: A doubling of, for example, the inflow hazard, leads to an almost doubling of the unemployment rate. The higher the unemployment rate, then, the more cyclically sensitive is an individual group's rate of joblessness.

Inspection of Figure 8 reveals that this observation can account entirely for the greater cyclical sensitivity of unemployment among youth, ethnic minorities and the less-educated in the current, and indeed all recessions over the sample period. Combining this with our earlier observation that the bulk of the differences in unemployment levels, and thereby of $\beta_{j}$, across groups can be

\footnotetext{
${ }^{18}$ Şahin, Song, and Hobijn (2009) explore this phenomenon using longitudinally-linked monthly CPS microdata to estimate labor market flows between unemployment, employment and nonparticipation. Consistent with Figure 8, they find that, for men, the employment to unemployment transition rate increased more than it did for women, while unemployment to employment transition rate declined proportionally across gender groups.
} 
attributed to differences in rates of entry into unemployment yields an interesting implication: The majority of the variation in both the levels and the cyclical sensitivity of group unemployment rates can be accounted for by differences in the level of inflow rates across groups.

\subsection{The Role of Job Loss in the Recession}

The previous sections have shown that unemployment inflows are a proximate driving force of the increase unemployment in the current recession, and that they play an important role in accounting for cross sectional differences in the level and cyclicality of unemployment across groups. It is tempting to conclude that this constitutes evidence that job loss has played a key role in the 2007 recession. In this section, we delve into this observation to uncover the mechanisms that can account for these elevated inflow rates.

We address two important conceptual distinctions. First, as mentioned above, estimates of the unemployment inflow rate, $s_{t}$ in equation (4), are based on the implicit assumption that all inflows into the unemployment pool originate from employment rather than nonparticipation. In fact, around 40 percent of the unemployment stock is accounted for by individuals (re-)entering the labor force. Consequently, estimates of $s_{t}$ conflate two economically distinct driving forces for entry into unemployment: flows from nonparticipation brought about by the process of labor force entry, and flows from employment to unemployment that are associated with elevated rates of job loss.

Second, job loss is often taken to mean a separation from an employer rather than an inflow into the unemployment pool, the distinction being that workers can, and frequently do, line up new jobs without an intervening unemployment spell, a point that has been made since Mattila (1974), and more recently by Fallick and Fleischman (2004) and Nagypál (2008). In what follows, we bring to bear a range of additional data that speak to these distinctions.

Unemployment Inflows by Reason. It is possible to distinguish among different sources of unemployment flows using publicly available monthly time series on the number unemployed by reason for unemployment, and the number unemployed for fewer than five weeks by reason from the CPS. We focus on three main reasons for unemployment: job losers (layoffs), job leavers (quits), and labor force entrants. ${ }^{19}$ An important benefit of this distinction is that the former two

\footnotetext{
${ }^{19}$ It is possible to further decompose job losers into temporary vs. permanent layoffs, and labor force entrants into new entrants and reentrants. We do not distinguish among these principally because the redesign of the CPS in 1994 led to substantial changes in the definition of these subgroups, and associated discontinuities in the respective time series. See Polivka and Miller (1998).
} 
categories originate from employment, while the latter originates from nonparticipation. This allows us to distinguish between employment to unemployment associated with job loss, and nonparticipation to unemployment flows that accompany labor force entry.

Elsby, Michaels and Solon (2009) describe how these data can be used to infer estimates of unemployment flows by reason for unemployment. ${ }^{20}$ Figure 9 plots estimates of the inflow rates by reason. As emphasized by Elsby et al., all of the observed countercyclicality in the aggregate inflow rate noted above is driven by a markedly countercyclical layoff inflow rate. The quit inflow rate is comparatively very low and mildly procyclical, thereby dampening the observed countercyclicality of aggregate inflows. In addition, inflows due to labor force entry are essentially acyclical, further moderating the rise in the aggregate inflow rate in times of recession.

The impression of Figure 9, one that is a unifying theme of the present paper, is that the behavior of inflows by reason in the current downturn is again very reminiscent of past recessions. The behavior of the layoff inflow rate in particular suggests a simple partitioning of recessionary episodes: Deep recessions, such as those starting in 1974, the Volcker disinflation period of the early 1980s, and the present downturn are characterized by markedly elevated layoff inflow rates; milder recessions, such as those starting in 1990 and 2001, are typified by a more modest increase in inflows due to layoffs. Again, the message of the 2007 recession is that severe modern recessions share many of the characteristics of deep recessions in the past.

Evidence from Labor Turnover. The fact that unemployment inflows have risen markedly in the current recession, and that layoff inflows have dominated that trend, is suggestive of job loss playing a key role in driving cyclical rises in unemployment. But it is not necessarily conclusive. As noted by Hall (2005), elevated rates of inflow into unemployment need not be the outcome of elevated rates of separation from employers: Increased inflows in times of recession can occur if workers increasingly are unable to line up new jobs immediately upon separation. Under this alternative hypothesis, countercyclical inflows are a symptom of declining rates of job finding among potential job-to-job movers, rather than of elevated rates of job loss.

\footnotetext{
${ }^{20}$ There is a slight difference between the methods used by Elsby, Michaels and Solon (2009) to compute inflow rates by reason for unemployment and that used by Shimer (2007) to compute the aggregate inflow rate. Elsby et al. use a discrete time correction for time aggregation bias, while Shimer uses a continuous time correction. Results in Elsby et al. suggest this difference is not quantitatively important.
} 
The current recession provides a unique opportunity to assess these competing hypotheses - it is the first full recession covered by the new Job Openings and Labor Turnover Survey (JOLTS). ${ }^{21}$ This is crucial for our present purpose because it provides a representative measure of the rate at which employed workers separate from their employers in the U.S. More formally, denote the separation rate from employers by $\sigma_{t}$, and the employment to unemployment inflow rate by $s_{t}^{e u}$. Note that a measure of the latter is given by the sum of the layoff and quit inflow rates presented above, $s_{t}^{e u}=s_{l, t}+s_{q, t}$. It follows that we can relate $\sigma_{t}$ and $s_{t}^{e u}$ simply according to:

$$
s_{t}^{e u}=p_{t} \sigma_{t}
$$

where $p_{t}$ denotes the probability that a worker who separates from her employer in month $t$ subsequently flows into unemployment.

Figure 10 plots the published JOLTS time series for the separation rate $\sigma_{t}$ and the employment to unemployment transition rate $s_{t}^{e u}$ implied by CPS data. This reveals a stark set of facts. First, there is a substantial difference between the separation rate and the employment-to-unemployment transition rate, a fact that is suggestive of the abundance of job-to-job transitions in the U.S. economy, as emphasized by Fallick and Fleischman (2004) and Nagypál (2008). Second, while the employment to unemployment inflow rate has increased in the current downturn, the total rate of separation of workers from employers has, if anything, fallen slightly. At first blush, then, it would seem that the elevated rates of inflow into unemployment during the current recession are driven wholly by reductions in the rate at which workers line up new jobs. The results of Figure 10 would seem to provide ample support for Hall's (2005) hypothesis that job loss has little to do with increased unemployment in times of recession.

We argue that such a conclusion would be premature. It has long been recognized that the relatively modest cyclical behavior of total separations masks substantial cyclicality in its constituent elements—quits and layoffs. Moreover, these tend to display markedly opposite cyclical patterns: The quit rate from employers moves procyclically, while the layoff rate moves countercyclically. ${ }^{22}$ Figure 11 plots economy-wide layoff and quit rates from JOLTS for the current

\footnotetext{
${ }^{21}$ JOLTS data are available only back to December 2000. Because of this, they miss part of the ramp-up in unemployment in the 2001 recession.

${ }^{22}$ See, for example, Slichter (1919), Woytinsky (1942), Akerlof, Rose, and Yellen (1988), and Anderson and Meyer (1994).
} 
downturn and reveals that, as with unemployment flows, the behavior of labor turnover in the current recession is again remarkably consistent with historical trends in these series.

Accounting for the distinction between quits and layoffs allows a more revealing investigation of the relationship between separations and unemployment inflows than in equation (6) above. The employment to unemployment transition rate can be decomposed as follows:

$$
s_{t}^{e u}=p_{l, t} \sigma_{l, t}+p_{q, t} \sigma_{q, t}=\underbrace{\left[\omega_{t} p_{l, t}+\left(1-\omega_{t}\right) p_{q, t}\right]}_{p_{t}} \sigma_{t}
$$

where subscripts $l$ and $q$ respectively denote layoffs and quits, $\sigma=\sigma_{l}+\sigma_{q}$ is the aggregate separation rate, and $\omega=\sigma_{l} / \sigma$ is the share of layoffs in aggregate separations. Equation (9) therefore highlights an additional channel by which employment to unemployment transitions may increase: through changes in the composition of separations that occur during recessions, $\omega$.

Figure 11 clarifies this point. It depicts the quit separation rate $\sigma_{q}$ from JOLTS along with the quit inflow hazard into unemployment $s_{q}$ derived from CPS data using the method described in the previous section. At all points in time, workers who quit their previous job face a very low probability of subsequently entering unemployment $-p_{q}$ averages just 16 percent over the sample period. Job-to-job flows drive an important wedge between separations and unemployment inflows due to quits. It is for this reason that quits account for only a small fraction of unemployment inflows. In addition, the implied series for $p_{q}$ displays no cyclical pattern: it has fallen steadily from approximately 20 percent in 2001 to 14 percent in 2009. These two observations - that $p_{q}$ is small, and that it has not risen in the current downturn - account for why the contribution of quits to increased unemployment inflows is not significant in the current downturn.

A quite different story holds for layoffs. Figure 11 shows that, at all points in time, workers laid off from their previous jobs face a very high probability of entering unemployment $-p_{l}$ averages 91 percent since 2001. Job-to-job flows do not appear to be prevalent among laid-off workers. Moreover, while the gap between the separation and inflow rates for layoffs closed in the early periods of the current downturn, the rise in $p_{l}$ accounts only for a small fraction of the overall rise in unemployment inflows, perhaps one-quarter of the overall rise in the layoff inflow rate.

Figure 11 therefore provides a unique perspective on the rise in unemployment inflows during the recession. As suggested by Hall (2005), elevated rates of entry into unemployment are not 
driven by increases in the overall rate at which workers separate from employers. But, in contrast to the claims of recent literature, job loss nonetheless plays a crucial role in accounting for recessionary unemployment. Instead, a different picture emerges: Increased inflows into unemployment can be traced to a shift in separations during the recession toward layoffs, who are very likely to flow into unemployment. Increases in the layoff rate have played a central role in accounting for increased rates of entry into unemployment in the current recession.

\section{Outlook for recovery in the labor market}

Until now, we have concentrated on analyzing the behavior of labor market stocks and flows associated with the rise in unemployment in the 2007 recession. In this section, we turn to the prospects for the labor market going forward.

Our point of departure is to return to Figure 6 which displays the behavior of unemployment flows during each postwar recession. Two features of Figure 6 provide a first glimpse of the central features that will guide the recovery. First, since the spike in the inflow rate has partially subsided, the key to any decline in unemployment in the future is a recovery of the outflow rate. Second, the decline in the outflow rate that has accompanied the 2007 recession has been much more severe than in past recessions. Thus, the recovery of the outflow rate is all the more salient in the present downturn for the future of the U.S. labor market.

One can think of the relative strength of the rebound in the outflow rate as being determined by two things. First, how many new job openings will be created? Second, for a given increase in the number of vacancies, how quickly does the pool of unemployed find new jobs?

\subsection{Vacancy creation}

Job creation reflects the overall health of the economy and it is expected that as the aggregate activity recovers, vacancy creation will also start to increase. However, there are many factors that affect the timing and level of vacancy creation during recoveries.

On the up side is the additional strength in vacancy creation due to the alleviation of the credit constraints that resulted from the financial crisis. Moreover, since the resolution of the financial crisis is likely to cause a substantial decline in aggregate and individual uncertainty, firms' 
willingness to hire could increase significantly. In particular, it implies a drastic reduction in the probability of a detrimental aggregate economic outcome. As Bernanke (1983) points out, such a reduction in the probability of "bad news" will increase the likelihood that firms make the decisions to invest and hire, which are costly to reverse.

There are also reasons to imagine that explanations of the jobless recoveries of 1990-91 and 2001 recessions are likely to be absent during the current episode. Willems and van Wijnbergen (2009) argue that labor hoarding can explain the jobless recoveries following the 1990 and 2001 recessions. Labor hoarding is more likely during shallow recessions, but is much less likely during the current deep recession, which has exhibited sharp rises in rates of job loss. Similarly, Van Rens (2004) and Koenders and Rogerson (2005) have argued that firms used the previous two recessions as an opportunity to improve their organizational efficiency and productivity. Since the 2002 to 2007 expansion was neither exceptionally long nor very strong, it seems that the forces that might have caused limited hiring after the 1990 and 2001 recessions are much less likely to have a large and persistent effect during this recovery. The strength in productivity growth in the second half of 2009 that led to the deviation from Okun's Law depicted in Figure 3 may suggest that these forces are present during the ongoing recovery, though.

On the downside, there is potentially a large amount of unused capacity in the economy in terms of labor input that firms can tap into before needing to hire additional workers which could cause the firms to wait to create new jobs. Currently workers who work part-time but who would have preferred to work full-time make up 6.7 percent of those employed. Daly, Hobijn, and Kwok (2009b), among others, have argued that the pace of hiring relative to output growth during the recovery could be slowed down because firms first increase the hours of those who are already employed but only part-time before they actually hire additional workers.

Finally, there are reasons to suspect that labor market changes that have taken place in the last two decades will render such sharp reversals in the labor market less likely. For example, there has been a decline in firms' use of temporary layoffs, eliminating the possibility of increasing employment at low cost. ${ }^{23}$ In addition, the sharp recovery following the 1980s recession may have been aided by the reversal of the disinflationary monetary policy that instigated the recession in the first place, a feature the current recession does not share.

\footnotetext{
${ }^{23}$ See Groshen and Potter (2003) for a detailed discussion.
} 


\subsection{Match efficiency and the Beveridge Curve}

An important concern for the strength of the recovery is that, even if firms create new jobs, it will be harder to match workers with the appropriate job openings. The main reason for this concern is depicted in Figures 12 and $13 .^{24}$ Figure 12 illustrates the relationship between the logarithmic deviations from Hodrick-Prescott filtered trends of vacancies and the unemployment rate, i.e. the Beveridge curve. Observations in the plot are classified in terms of 'not during a recession', 'during a recession before 2007', and 'during the 2007 recession.' The bold dashed line is the regression line based on all observations before 2008 and the light dashed lines delimit the $90 \%$ confidence interval around this regression line. As noted by Shimer (2005), historically there has been a remarkably stable negative association between job openings and the unemployment rate. As can be seen from the figure, during the fall of 2009 the unemployment rate has been higher than would be implied by the historical Beveridge curve.

Figure 13 investigates the sources of this deviation from past trends. It plots the logarithmic deviations from Hodrick-Prescott filtered trends of the outflow rate, $f_{t}$, and the ratio of the number of vacancies to the number of unemployed persons, often referred to as labor market tightness. Shimer (2005) refers to the remarkably stable positive relationship as the matching function. Figure 13 reveals that the recent divergence from the Beveridge curve can be traced to the outflow rate being substantially lower than would be suggested by the matching function relationship observed over much of the postwar period. The substantial decline in the outflow rate witnessed in the latter part of 2009 in Figure 6 therefore represents a significant outlier in the context of the historical matching function.

The breakdown of the Beveridge curve and matching function relations in Figures 12 and 13 is evocative of the similar breakdown in match efficiency that occurred during the European unemployment problem of the 1980s and 1990s (see, for example, Figure 11 in Layard, Nickell, and

\footnotetext{
${ }^{24}$ Figures 12 and 13 are updated versions of Figures 4 and 6 in Shimer (2005). For expositional purposes we plot monthly rather than quarterly data. To account for this change in frequency, we use a value of 2700000 for the smoothing parameter of the HodrickPrescott filter which is used to filter the trend in log levels of all variables. This corresponds to the value that Shimer (2005) uses corrected for the change in frequency using the factor for stock variables derived by Ravn and Uhlig (2002). The vacancy series is based on Barnichon (2009), who builds a vacancy posting index for the years 1951 to 2009 by combining information from the total print and online help-wanted advertising indexes with JOLTS. As discussed in Shimer (2005), the growth of internet vacancy posting since the mid 1990s, and newspaper consolidation and Equal Opportunities legislation in the 1960s, can make it hard to compare the level of vacancies over time. Shimer uses a low-frequency HP filter to remove these trends. In addition, the series we use from Barnichon (2009) are robust to a range of possible higher-frequency paths for the diffusion of internet vacancy postings. The cyclical component of the vacancy series that we use moves consistently with economic activity over the business cycle.
} 
Jackman, 1991). This raises the concern that the U.S. economy will be plagued by the persistently high unemployment rates that these European economies experienced well into the 1990s-socalled hysteresis. In practice, hysteresis can arise through a number of channels. We highlight a few of these possibilities here, and provide a sense of their relevance in the current downturn.

Mismatch. One potential reason for a persistent reduction in match efficiency is a mismatch between the skills and the skill requirements of job openings. ${ }^{25}$ For example, Groshen and Potter (2003) have argued that the jobless recoveries after the 1990 and 2001 recessions were in large part due to structural reallocation of workers across sectors in the economy. They claim that this reallocation led to a mismatch in skill-mix that resulted in a slower adjustment of the labor market than in previous recessions. More recently, Phelps (2008) has reiterated this concern in relation to construction and finance workers in the 2007 recession.

This reallocation argument suggests that workers that were employed in sectors in structural decline will have a harder time finding jobs than other workers. That is, it implies a divergence in outflow rates from unemployment between those who previously were employed in industries in structural decline versus those of other workers. Figure 14 addresses this question. It shows the unemployment outflow hazard rates conditional on the industry in which a person was employed at the start of the unemployment spell. If anything, we have actually seen a convergence of these outflow rates rather than the divergence implied by the structural reallocation argument. ${ }^{26}$

Besides a mismatch in skills, an additional concern is the potential emergence of geographical disparities in the location of workers and job openings. This has come into focus in the current recession amid concerns that, given the decline in house prices that accompanied the recession, job applicants are more reluctant to apply for and accept jobs that are not within commuting distance from their current residence and would require them to sell their homes. Ferreira, Gyourko and Tracy (2009) find that homeowners with negative equity are less likely to move by using data from

\footnotetext{
${ }^{25}$ Related to this argument, Aaronson, Rissman, and Sullivan (2004) point out that there did not seem to be a higher need to reallocate labor across sectors in the 1990 and 2001 recessions, which were accompanied by jobless recoveries, than during earlier ones. Valletta and Cleary (2009) find the same for the 2007 recession.

${ }^{26}$ While suggestive, this need not imply that skill mismatch is not an issue in the current recession. For example, it may be the case that skill mismatch nevertheless exists, but that it occurs within industry classifications. In such a case, disaggregation by industry would be too broad to detect an increase in skill mismatch. However, estimation of further disaggregated unemployment flows is limited by the increased sampling variance that accompanies additional splitting of the CPS sample.
} 
American Housing Survey for 1985-2005. ${ }^{27}$ Their results cannot be easily extrapolated to the current recession but still point to a potentially important negative effect of housing-related problems on the labor market recovery since geographic mobility is an important part of adjustment to shocks in the U.S. labor market as emphasized by Blanchard and Katz (1992). ${ }^{28}$

Sclerosis and duration dependence. Associated with the record rise in the unemployment rate has been a surge in long-term unemployment. The fraction of the labor force that has been unemployed for more than six months has increased by a staggering 3.5 percentage points to a postwar high of 4 percent, 1.5 percentage points higher than the previous peak in 1983. Likewise, average unemployment duration has risen to an historic high of 30 weeks, the mirror image of the historic low in the unemployment exit rate noted in section 2. Here we explore the effects of these depressed unemployment flows on the evolution of the recovery-what Bentolila and Bertola (1990) and Blanchard (2000) have referred to as sclerosis in the European context. ${ }^{29}$

A first potential source of sclerosis relates to the effect of reductions in the level of unemployment outflow rates on the speed of adjustment of the unemployment rate. This point is clarified by equation (4) above. There, reductions in the pace of worker reallocation, $s_{t}+f_{t}$, lead to reductions in the responsiveness of unemployment to changes in flow steady-state unemployment, $u_{t}^{*}=s_{t} /\left(s_{t}+f_{t}\right)$. This matters for the recovery of unemployment in the wake of the current recession: A by-product of the historically low outflow rate reached during the 2007 recession is that the rate of convergence of unemployment to its flow steady state, $\lambda_{t}$ in equation (4), also has arrived at a postwar low. Thus, even if firms start to hire again, the outflow rate rebounds, and flow steady-state unemployment recovers, the actual unemployment rate may exhibit a delayed reaction.

Quantitatively, however, we find that these effects are likely to be small. While the recent trough in the monthly outflow rate of 0.24 is a record low by historical U.S. standards, it remains very high relative to the standards of the European unemployment problem of the 1980s, when

\footnotetext{
${ }^{27}$ Some commentators on the current recession have pointed to evidence that the rate of domestic migration in the U.S. has reached a postwar low in recent data. However, it is difficult to discern how much of this is associated with the recession-rates of internal migration have been falling in the U.S. as a secular phenomenon since the mid-1980s (see, for example, Frey, 2009).

${ }^{28}$ This implication of Blanchard and Katz (1992) has been the source of some dispute, however. See, for example, Rowthorn and Glyn (2006).

${ }^{29}$ We use the term sclerosis in the sense of Blanchard (2000): "Flows decrease, individual unemployment duration increases, and so does the proportion of long-term unemployed."
} 
monthly outflow rates fell below 0.08 in many European economies. ${ }^{30}$ To put this in perspective, the half-life of a deviation of unemployment from flow steady state, which stood at a little over one month prior to the current downturn in the U.S., has risen to just under three months in recent data for the U.S., but is not even close to the values of nine months to a year experienced in Europe in 1980s and early 1990s. ${ }^{31}$

A second source of sclerosis is the persistence in the decline of the outflow rate itself. Previous literature has identified the duration composition of unemployment to be a key potential driving force for such persistence (Blanchard, 2000). Specifically, a pervasive feature of unemployment flows in the U.S. is that average rates of outflow from unemployment decline with the duration of unemployment spells_-so-called negative duration dependence — a point noted since Kaitz (1970), and made more recently by Shimer (2008). ${ }^{32}$ Several explanations have been proposed for such an outcome, including the depreciation of skills of the unemployed (Pissarides, 1992; Ljungqvist and Sargent, 1998); the ranking of job applicants by the duration of their unemployment spell (Blanchard and Diamond, 1994); and statistical discrimination by employers against the long-term unemployed (Lockwood, 1991).

Here we highlight potential reasons for why such duration dependence can matter for the evolution of the labor market over the cycle. Noting that the aggregate outflow probability $F_{t}$ can be expressed as a share-weighted sum of the outflow probabilities faced by each duration group $d$, $F_{t}=\sum_{d} \omega_{d t} F_{d t}$, it follows that changes in the aggregate outflow probability over time can be decomposed according to

$$
\Delta F_{t}=\sum_{d}\left(\omega_{d t} \Delta F_{d t}+\Delta \omega_{d t} F_{d t-1}\right)
$$

Equation (10) summarizes two potential concerns over the role of duration dependence in the recession. First, in the context of the surge in long-term unemployment encountered in the present recession, it is tempting to hypothesize that those with longer unemployment spells have increasingly become disenfranchised from the labor market, leading to a disproportionate decline in

\footnotetext{
${ }^{30}$ Hobijn and Șahin (2009, Table 1) report average duration distributions of unemployment spells, and Elsby, Hobijn and Șahin (2009) document the behavior of inflow and outflow rates over time for a broad number of OECD countries.

${ }^{31}$ These are computed based on the estimates in Elsby, Hobijn and Șahin (2009, Figure 3).

${ }^{32}$ As noted by Kaitz (1970), this may take the form of "spurious" duration dependence that arises from dynamic selection (Salant, 1977), or "true" duration dependence whereby the accumulation of unemployment duration has a causal effect on exit rates.
} 
their outflow rates. Such an effect would be captured by the first term in parentheses in equation (10).

Figure 15 addresses this by presenting time series for a range outflow rates for workers with different unemployment durations. Specifically, we use longitudinally-linked monthly CPS microdata from 1976 to compute the probability that an unemployed worker of a given duration exits unemployment within a month. Figure 15 plots the associated hazards for durations equal to less than 1,1 to 3,3 to 6 , and 6 or more months. Consistent with the literature on negative duration dependence in unemployment exit rates, the hazards for exiting unemployment decline as duration rises. More importantly for the hypothesis under discussion, however, there is no evidence that exit rates have fallen disproportionately among the high duration unemployed in the last five recessions. Rather, just as we saw in Section 2.2 on unemployment flows by group, the cyclicality of outflow rates displays an extraordinary regularity across duration groups. In sum, there appears to be little evidence to suggest that elevated rates of joblessness are a symptom of diminished employment opportunities of the long-term unemployed in this, or any other recession. ${ }^{33}$

However, equation (10) also reveals that duration dependence can affect the cyclicality of the aggregate outflow rate via changes in the duration structure of unemployment, $\Delta \omega_{d t}$. Formally, a simple description of the stock of unemployed workers of duration $d$ over time $t$ is

$$
u_{d t+1}=\left(1-F_{d-1 t}\right) u_{d-1 t},
$$

with initial condition $u_{0 t}$ given by the unemployment inflow derived in section 2 . It follows that the unemployment share of duration group $d$ is given by

$$
\omega_{d t+1}=\left(1-F_{d-1 t}\right)\left(u_{t} / u_{t+1}\right) \omega_{d-1 t} .
$$

Equation (12) has significant implications for the evolution of the outflow rate during the recovery. It reveals that the unemployment shares of the high-duration unemployed are persistent, and in particular depend on the outflow rates faced by low-duration unemployed that prevailed in the past. Intuitively, even if outflow rates move uniformly across duration groups during the recession, the historic decline in outflow rates as a whole can result in a persistent residue of long-term

\footnotetext{
${ }^{33}$ Interestingly, this conclusion mirrors the results of Machin and Manning (1999) in their detailed analysis of the long-term unemployment problem in Europe. In their words: "while the longterm unemployed do leave unemployment at a slower rate than the shortterm unemployed, this has always been the case and their relative outflow rate has not fallen over time."
} 
unemployed workers who exit unemployment slowly, depressing aggregate outflow rates in the future.

To illustrate the potential importance of this mechanism Figure 16 presents an illustrative exercise: It simulates the future evolution of the aggregate outflow rate in the wake of the current recession, assuming that outflow rates for each duration group, as well as the aggregate inflow rate, rebound in proportion to that witnessed in the 1983/4 recovery. For purposes of comparison, Figure 16 also plots an alternative path for the aggregate outflow rate, indexed to the actual recovery observed in 1983/4.

Figure 16 suggests that the accumulation of long-term unemployed individuals in the present recession can indeed have quantitatively important effects on the rebound in the outflow rate during the recovery. While the aggregate outflow rate rebounded by around 30 percent in the 1983-84 recovery, the simulated path for the upcoming recovery augurs a more lackluster 15 percent. By this reckoning, the overhang of long-term unemployed workers would yield a recovery in unemployment half as rapid as that seen in the mid-1980s.

The difference between the 1983-based and the simulated counterfactual path of the aggregate finding rate is largely due to the low levels of the outflow rates at the end of 2009 . Hence, even if these rates rebound at the same growth rate as in 1983, they would remain at a lower level than in 1983 and this would lead to a higher average duration of unemployment, even in the long run. Though this is definitely a cause for concern, it is important to note that it is unlikely that this mechanism will lead to the degree of persistence in the outflow rate that led to the degree of hysteresis seen in European unemployment. The simple reason is that the long-term unemployed in the United States flow out of unemployment at a rate that is four times higher than the aggregate outflow rates in Continental Europe reported in Elsby, Hobijn, and Șahin (2009).

The role of Emergency Unemployment Compensation. One particularly salient reason for a temporary decline in match efficiency relates to the temporary extension of Emergency Unemployment Compensation (EUC) that began in June 2008. In addition to the regular 26 weeks, one could be eligible to 53 additional weeks of EUC as long as the Congress continues to extend it. $^{34}$ Conventional economic theory suggests this lengthening of the expected duration of

\footnotetext{
${ }^{34}$ EUC is divided into four tiers (20 weeks, then 14, then 13, and finally another 6 weeks); one must reapply when each tier expires. In addition to these 53 extra weeks, most states offer Extended Benefits (EB) up to 20 weeks. The number claiming EB has been relatively small.
} 
unemployment benefits will place downward pressure on the unemployment outflow rate seen in Figure 13, as those searching for a job become more selective about which job offers they accept.

Existing research on the effects of unemployment insurance benefits suggests that there is a strong positive relationship between the maximum duration of UI benefits and unemployment spell duration. ${ }^{35}$ Estimates suggest that a one week increase in potential benefit duration is associated with increases in the average duration of the unemployment spells of UI recipients of around 0.08 to 0.20 weeks. According to these estimates, then, a 53-week extension in potential benefit duration would be associated with a 4.2 to 10.6 week increase in unemployment duration among UI recipients. ${ }^{36}$ Since the fraction of unemployed workers now claiming some form of UI benefits has averaged 50 percent in the current recession, this suggests something like a 2.1 to 5.3 week increase in overall unemployment duration. Over the course of the current recession, average unemployment duration surged from 16.5 weeks to 30.2 weeks, a 13.7 week increase. This back-of-the-envelope calculation therefore suggests that EUC can account for as much as 15 to 40 percent of the rise in aggregate unemployment duration, a potentially substantial effect. In terms of the unemployment rate, this corresponds to between 0.7 and 1.8 percentage points of the 5.5 percentage point rise in the unemployment rate witnessed in the current recession.

There are reasons to believe, however, that the effect of extended UI benefits in the current recession on the duration of unemployment is likely to be at the lower end of these estimates. Many of the larger estimates of the effect of benefit duration on unemployment duration are based on data from the 1970s and 1980s when temporary layoffs, who are more responsive to the generosity of UI, comprised a larger fraction of unemployment. In addition, many of the larger estimates in the literature are based on empirical strategies that identify the effect of UI by exploiting differences in benefit schedules across states and time. As Card and Levine (2000) emphasize, a potential difficulty of this approach is that many states extend UI benefits as a response to poor job finding prospects in recessions, overstating the true disincentive effect of the UI. ${ }^{37}$ Indeed, Card and Levine's estimates based on an exogenous policy change lie at the bottom of the range of effects, suggesting a more modest impact of EUC.

\footnotetext{
${ }^{35}$ See Card and Levine (2000), Katz and Meyer (1990), Krueger and Meyer (2002), Meyer (1990), and Moffitt (1985).

${ }^{36}$ Note that this calculation assumes that, upon entering unemployment, all unemployed workers anticipate that benefit duration will be extended by 53 weeks. In that sense it is an upper bound on the response.

${ }^{37}$ Consistent with this, in their study of the effect of benefit duration for a policy change that is exogenous to labor market conditions, Card and Levine (2000) obtain an estimate that lies at the bottom end of the range we report.
} 
Taken together, our analysis of the decline in match efficiency observed in the latter stages of the current recession points to two potentially important driving forces: The existence of a substantial residue of long-term unemployed workers with relatively weak search effectiveness, and the extension of Emergency Unemployment Compensation. Taken separately, one might imagine that the temporary nature of EUC will imply that the labor market will recover as extended UI benefits are withdrawn, while the structural nature of the long-term unemployment problem will endure well into the recovery. However, there are likely to be important interactions between the two. A major impetus for the introduction of the EUC program was in fact the rise in long-term unemployment that accompanied the recession. Thus, an enduring long-term unemployment problem could mean that the political will to withdraw EUC may take some time to materialize.

\section{Conclusion}

Our detailed analysis of the adjustment of the labor market in the current downturn reveals it to be the deepest deterioration in labor market outcomes on record in the postwar era. Every indicator of labor market activity suggests that the recession has been unique both in its depth and duration. Rates of joblessness among all groups in the labor market have reached historic postwar highs. There is little doubt that it is a Great Recession.

Nonetheless, our analysis suggests that many of the features of labor market dynamics in the Great Recession until the latter half of 2009 are strikingly similar to those seen in earlier recessions. This is true of the behavior of employment and labor force participation rate, the use of the intensive vs. extensive margins in the adjustment of labor input, and in terms of the demographic groups most affected, with young, male, less-educated, workers from ethnic minorities being hit harder.

In terms of the underlying flows, just as in prior deep recessions increased joblessness in the downturn can be traced to both increased rates of inflow, as well as increased duration, with inflows being relatively more important early on in the downturn. This suggests that the more modest response of unemployment inflows in the 1990 and 2001 recessions is a feature of mild recessions, rather than of modern ones. 
Further analysis of worker turnover data from the new Job Openings and Labor Turnover Survey provides a unique perspective on the driving forces of job loss in the 2007 recession. Recent literature has emphasized the relatively acyclical behavior of the rate at which workers separate from employers, suggesting that job loss plays only a limited role in driving recessionary unemployment. Combining data from JOLTS and the CPS reveals that increased inflows into unemployment have been driven predominantly by a change in the composition of separations toward layoffs, who are very likely to become unemployed, and away from quits, who are very likely to flow to a new job upon separation. Thus, contrary to recent claims, increases in layoffs have played a key role in driving increased unemployment in the recession.

Despite the similarities of the labor market response in the early stages of the current recession with prior downturns, more recent evidence suggests there has been an important divergence with past trends. Most prominently, rates of exit of unemployed workers from joblessness have slowed to record levels, drawing into focus the importance of a rebound in outflow rates for the recovery. Recent data point to two key factors: The record rise in long-term unemployment associated with the recession is likely to yield a persistent overhang of workers facing long unemployment spells, slowing the recovery. In addition, the extension of Emergency Unemployment Compensation starting in June 2008 is likely to have led to a modest increase in long-term unemployment in the recession.

Despite these unfavorable forces, recent data suggest that the problems facing the U.S. labor market going forward are unlikely to be as severe as the European-style hysteresis problem of the 1980s. While the jobless in the U.S. are exiting unemployment at a historically slow rate, they nonetheless leave unemployment as much as four times faster than those in continental Europe in the 1980s. Looking ahead, then, a tentative expectation is for a lackluster recovery, but one not nearly as dismal as seen in Europe in the past. 


\section{References}

Aaronson, Daniel, Ellen R. Rissman, and Daniel G. Sullivan (2004), "Can Sectoral Reallocation Explain the Jobless Recovery?" Federal Reserve Bank of Chicago Economic Perspectives, QII, 36-49.

Abraham, Katharine G. and Robert Shimer (2001), "Changes in Unemployment Duration and Labor-Force Attachment." In The Roaring Nineties: Can Full Employment Be Sustained?, ed. Alan B. Krueger and Robert M. Solow, 367-420. New York: Russell Sage Foundation and Century Foundation Press.

Akerlof, George A., Andrew K. Rose, and Janet L. Yellen (1988), "Job Switching and Job Satisfaction in the U.S. Labor Market," Brookings Papers on Economic Activity, 1988(2): 495582.

Anderson, Patricia M. and Bruce D. Meyer (1994), "The Extent and Consequences of Job Turnover," Brookings Papers on Economic Activity: Microeconomics: 177-236.

Baker, Michael (1992), “Unemployment Duration: Compositional Effects and Cyclical Variability," American Economic Review, 82(1): 313-21.

Barnichon, Regis (2009), "Vacancy Posting, Job Separation and Unemployment Fluctuations," Federal Reserve Board, Finance and Economics Discussion Series 2009-35.

Bernanke, Ben S. (1983), "Irreversibility, Uncertainty, and Cyclical Investment," Quarterly Journal of Economics, 98, 85-106.

Blanchard, Olivier Jean (2000), “The Economics of Unemployment: Shocks, Institutions, and Interactions." Lionel Robbins Lectures.

Blanchard, Olivier Jean and Peter Diamond (1990), "The Cyclical Behavior of the Gross Flows of U.S. Workers," Brookings Papers on Economic Activity, 1990 (2): 85-143.

Blanchard, Olivier Jean and Peter Diamond (1994), "Ranking, Unemployment Duration and Wages," Review of Economic Studies 61(3): 417-434.

Blanchard, Olivier Jean and Lawrence F. Katz (1992), "Regional Evolutions," Brookings Papers on Economic Activity, 1992 (1): 1-76.

Braun, Helge, Reinout De Bock, and Riccardo DiCecio (2006), "Aggregate Shocks and Labor Market Fluctuations," Working Paper No. 2006-004A, Federal Reserve Bank of St. Louis.

Clark, Kim B., and Lawrence H. Summers (1981), "Demographic Differences in Cyclical Employment Variation," Journal of Human Resources, 16, 6 1-79.

Card, David and Phillip B. Levine (2000), "Extended benefits and the duration of UI spells: evidence from the New Jersey extended benefit program," Journal of Public Economics, 78, 107-138.

Daly, Mary, Bart Hobijn, and Joyce Kwok (2009a), "Labor Supply Responses to Changes in Wealth and Credit," FRB-SF Economic Letter 2009-05.

Daly, Mary, Bart Hobijn, and Joyce Kwok (2009b), “Jobless Recovery Redux?” FRB-SF Economic Letter 2009-18. 
Davis, Steven J. (2006), "Job Loss, Job Finding, and Unemployment in the U.S. Economy over the Past Fifty Years: Comment," In NBER Macroeconomics Annual 2005, ed. Mark Gertler and Kenneth Rogoff, 139-57. Cambridge, MA: MIT Press.

Elsby, Michael W. L., Ryan Michaels, and Gary Solon (2009), "The Ins and Outs of Cyclical Unemployment," American Economic Journal: Macroeconomics, 1:1, 84-110.

Elsby, Michael W. L., Bart Hobijn, and Ayşegül Şahin (2009), "Unemployment Dynamics in the OECD," NBER Working Paper 14617.

Fallick, Bruce, and Charles Fleischman (2004), "Employer-to-Employer Flows in the U.S. Labor Market: The Complete Picture of Gross Worker Flows," Finance and Economics Discussion Series 2004-34. Washington: Board of Governors of the Federal Reserve System.

Farber, Henry S., and Bruce Western (2010), "The Distribution of Unemployment, Employment, and Hours in the Current Recession: A Preliminary Look," mimeo Princeton University.

Ferreira, Fernando, Joseph Gyourko, and Joseph Tracy (2008), "Housing Busts and Household Mobility," NBER Working Paper 14310.

Frey, William H. (2009). "The Great American Migration Slowdown: Regional and Metropolitan Dimensions," Washington DC: Brookings Research Report.

Fujita, Shigeru and Garey Ramey (2009), "The Cyclicality of Job Loss and Hiring," International Economic Review, 50, 415-430.

Gomme, Paul, Richard Rogerson, Peter Rupert, and Randall Wright (2004), "The Business Cycle and the Life Cycle," In NBER Macroeconomics Annual 2004, ed. Mark Gertler and Kenneth Rogoff, 415-592. Cambridge, MA: MIT Press.

Gordon, Robert J., (2010), “Okun's Law, Productivity Innovations, and Conundrums in Business Cycle Dating," mimeo Northwestern University.

Groshen, Erica L. and Simon Potter (2003), "Has Structural Change Contributed to a Jobless Recovery?" Current Issues in Economics and Finance, 9-8.

Hall, Robert E. (2005), "Job Loss, Job Finding, and Unemployment in the U.S. Economy over the Past Fifty Years,” NBER Macroeconomics Annual 2005, ed. Mark Gertler and Kenneth Rogoff, 101-37. Cambridge, MA: MIT Press.

Hall, Robert E. (2007), "How Much do We Understand about the Modern Recession?" Brookings Papers on Economic Activity, 2007 (2), 13-28.

Hobijn, Bart, and Ayşegül Şahin (2009) "Job-Finding and Separation Rates in the OECD," Economics Letters, 104, 107-111.

Kaitz, Hyman (1970), "Analyzing the Length of Spells of Unemployment," Monthly Labor Review, 93(11): 11-20.

Katz, Lawrence F., and Bruce D. Meyer (1990), "The Impact of the Potential Duration of Unemployment Benefits on the Duration of Unemployment," Journal of Public Economics 41, 45-72. 
Kennan, John (2006), "Job Loss, Job Finding, and Unemployment in the U.S. Economy over the Past Fifty Years: Comment," In NBER Macroeconomics Annual 2005, ed. Mark Gertler and Kenneth Rogoff, 159-64. Cambridge, MA: MIT Press.

Koenders, Kathryn, and Richard Rogerson (2005), "Organizational Dynamics Over the Business Cycle: A View on Jobless Recoveries," Federal Reserve Bank of St. Louis Review, 87, 555-579.

Krueger, Alan B. and Bruce D. Meyer (2002), "Labor Supply Effects of Social Insurance, " In Handbook of Public Economics vol. 4, edited by Alan Auerbach and Martin Feldstein, Amsterdam: North Holland, 2002.

Kydland, Finn E. (1984), "Labor-Force Heterogeneity and the Business Cycle," CarnegieRochester Conference Series on Public Policy, 21, 173-208.

Layard, Richard, Stephen Nickell, and Richard Jackman (1991), Unemployment: Macroeconomic Performance and the Labour Market. Oxford: Oxford University Press.

Lockwood, Benjamin (1991), "Information Externalities in the Labour Market and the Duration of Unemployment." Review of Economic Studies 58(4): 733-753.

Ljungqvist, Lars and Thomas J. Sargent (1998), “The European Unemployment Dilemma,” Journal of Political Economy, 106, 514-550.

Machin, Stephen and Alan Manning, "The Causes and Consequences of Longterm Unemployment in Europe," in O. Ashenfelter and D. Card (ed.), Handbook of Labor Economics, 3, 3085-3139, Elsevier.

Marston, Stephen T. (1976), "Employment Instability and High Unemployment Rates," Brookings Papers on Economic Activity, 1976(1): 169-203.

Mattila, J. Peter (1974), "Job Quitting and Frictional Unemployment," American Economic Review, 64(1), 235-239.

Meyer, Bruce D. (1990), “Unemployment insurance and unemployment spells,” Econometrica 58, 757-782.

Mincer, Jacob (1991). "Education and unemployment” NBER Working Paper, No. 3838.

Moffitt, Robert (1985), "Unemployment insurance and the distribution of unemployment spells," Journal of Econometrics 28,85-101.

Nagypál, Éva (2008), “Worker Reallocation over the Business Cycle: The Importance of Employerto-Employer Transitions," mimeo, Northwestern University.

Nalewaik, Jeremy J. (2010), "Report on the Income- and Product- Side Estimates of U.S. Output Growth," Brookings Papers on Economic Activity, this issue.

Okun, Arthur M. (1962), "Potential GNP: Its Measurement and Significance," Proceedings of the Business and Economics Statistics Section of the American Statistical Association, pp. 98-104.

Perry, George L. (1972), "Unemployment Flows in the U.S. Labor Market," Brookings Papers on Economic Activity, 1972(2): 245-78.

Phelps, Edmund (2008), "U.S. Monetary Policy and the Prospective Structural Slump," Speech to the 7th Annual BIS Conference on Monetary Policy, Luzern, Switzerland. 
Pissarides, Christopher A. (1992), "Loss of skill during unemployment and the persistence of employment shocks.” Quarterly Journal of Economics 107(4): 1371-1391.

Polivka, Anne E. and Stephen M. Miller (1998), "The CPS after the Redesign: Refocusing the Economic Lens," In Labor Statistics Measurement Issues, ed. John Haltiwanger, Marilyn E. Manser, and Robert Topel, 249-86. Chicago: University of Chicago Press.

Ravn, Morten O, and Harald Uhlig (2002), "On Adjusting the Hodrick-Prescott Filter for the Frequency of Observations," Review of Economics and Statistics, 84, 371-374.

Rowthorn, Robert and Glyn, Andrew J. (2006) "Convergence and Stability in U.S. Employment Rates," Contributions to Macroeconomics: Vol. 6 : Iss. 1, Article 4.

Șahin, Ayşegül, Joseph Song, and Bart Hobijn (2009), "The Unemployment Gender Gap During the Current Recession," Current Issues in Economics and Finance, 16-2.

Salant, Stephen W. (1977), "Search Theory and Duration Data: A Theory of Sorts," Quarterly Journal of Economics, 91(1): 39-57.

Shimer, Robert (1998), "Why is the U.S. Unemployment Rate So Much Lower?" In NBER Macroeconomics Annual, ed. by Ben Bernanke and Julio Rotemberg, vol. 13. MIT Press, Cambridge, MA, 11-61.

Shimer, Robert (2001), “The Impact of Young Workers on the Aggregate Labor Market," Quarterly Journal of Economics, 116, 969-1008.

Shimer, Robert (2005), "The Cyclical Behavior of Equilibrium Unemployment and Vacancies," American Economic Review, 95, 25-49.

Shimer, Robert (2007), "Reassessing the Ins and Outs of Unemployment," NBER Working Paper 13421.

Shimer, Robert (2008), "The Probability of Finding a Job," American Economic Review, 98(2): 268-273.

Slichter, Sumner H. (1919), The Turnover of Factory Labor, New York: D. Appleton and Company.Valletta, Robert, and Aisling Cleary (2009), "Sectoral Reallocation and Unemployment," FRB-SF Economic Letter 2008-32.

Van Rens, Thijs (2004), “Organizational Capital and Employment Fluctuations," Universitat Pompeu Fabra - Economics Working Papers 944.

Willems, Tim, and Sweder van Wijnbergen (2009), "Imperfect Information, Lagged Labor Adjustment and the Great Moderation," Tinbergen Institute Discussion Paper 09-063/2.

Woytinsky, W. S. (1942), Three Aspects of Labor Dynamics, Washington, DC: Social Science Research Council.

Yashiv, Eran (2008), "U.S. Labor Market Dynamics Revisited," Scandinavian Journal of Economics, 109(4): 779-806. 
Table 1. Ratio of the Rise in Group Unemployment Rate to the Rise in the Overall Unemployment Rate by Recession

\begin{tabular}{|c|c|c|c|c|c|c|c|}
\hline & & $\begin{array}{c}\text { Average } \\
\text { unemployment } \\
\text { rate }\end{array}$ & 1980 & 1981-1982 & 1990-1991 & 2001 & Current \\
\hline \multicolumn{2}{|c|}{ Change in unemployment rate } & & $1.9 \%$ & $3.3 \%$ & $2.3 \%$ & $2.2 \%$ & $5.5 \%$ \\
\hline \multirow[t]{2}{*}{ Gender } & Male & $6.2 \%$ & 1.42 & 1.19 & 1.13 & 1.14 & 1.19 \\
\hline & Female & $6.3 \%$ & 0.43 & 0.75 & 0.85 & 0.84 & 0.78 \\
\hline \multirow[t]{3}{*}{ Age } & $16-24$ & $12.6 \%$ & 1.58 & 1.28 & 1.57 & 1.68 & 1.67 \\
\hline & $25-54$ & $5.0 \%$ & 1.0 & 1.02 & 0.92 & 0.98 & 0.99 \\
\hline & $55+$ & $3.6 \%$ & 0.22 & 0.65 & 0.90 & 0.60 & 0.66 \\
\hline \multirow[t]{4}{*}{ Education } & Less than High School & $8.8 \%$ & 1.36 & 1.61 & 2.03 & 1.31 & 1.60 \\
\hline & High School & $5.4 \%$ & 1.38 & 1.27 & 1.08 & 0.97 & 1.30 \\
\hline & Some College & $4.3 \%$ & 0.93 & 0.75 & 0.99 & 1.22 & 1.07 \\
\hline & College or Higher & $2.6 \%$ & 0.19 & 0.44 & 0.45 & 0.79 & 0.58 \\
\hline \multirow[t]{4}{*}{ Race } & White & $5.5 \%$ & 0.96 & 0.92 & 0.87 & 0.87 & 0.91 \\
\hline & Black & $12.1 \%$ & 1.30 & 1.67 & 1.40 & 1.86 & 1.29 \\
\hline & Hispanic & $8.8 \%$ & --- & --- & 1.67 & 0.90 & 1.35 \\
\hline & Asian & $4.6 \%$ & --- & --- & --- & 1.29 & 0.80 \\
\hline
\end{tabular}

Notes: Average unemployment rates are based on data from June 1976 to January 2010, except for Hispanics, for whom data are available only from January 1982 to January 2010, and Asians for January 2000 to January 2010. 
Figure 1. Unemployment Rate, 1948-2009

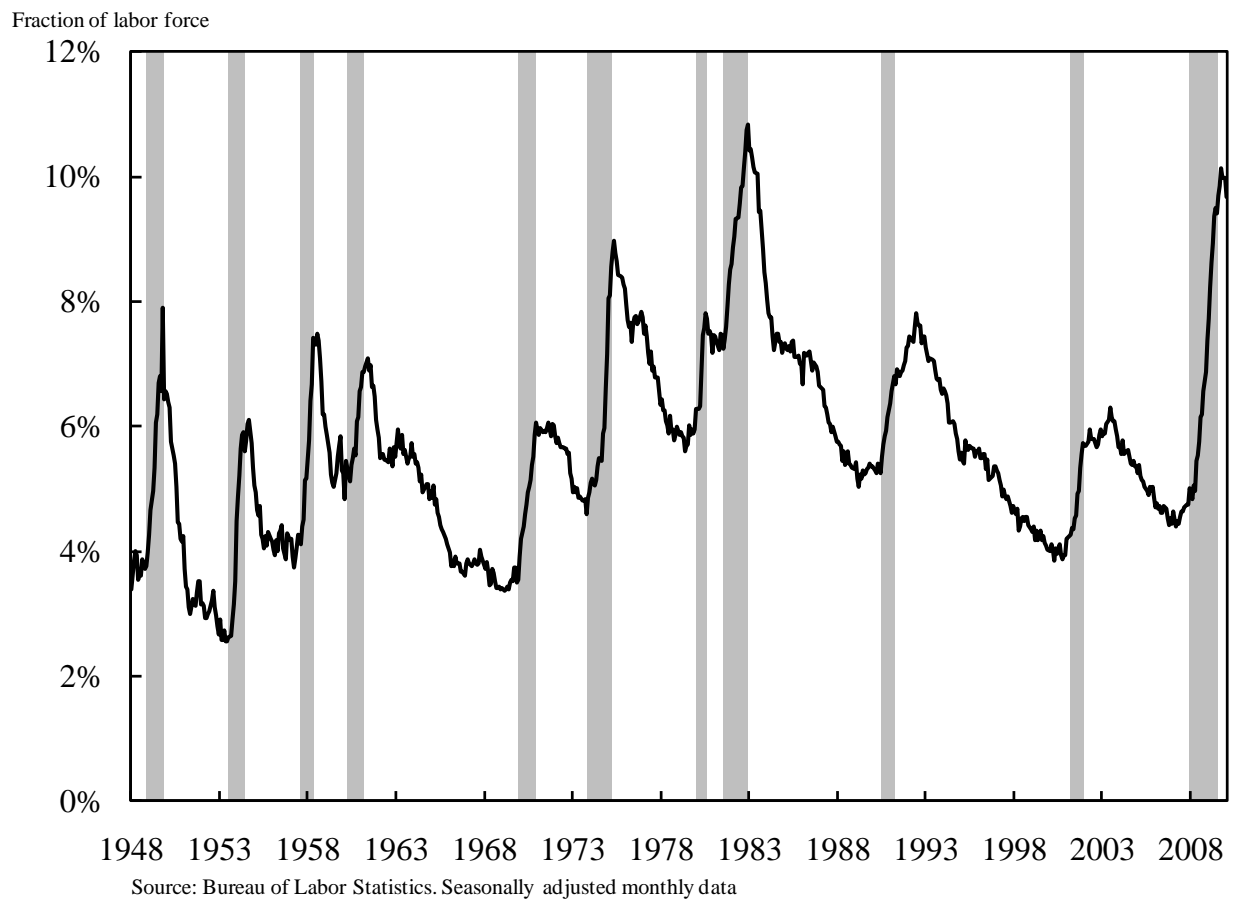

Figure 2. Deviation from Trend in Employment and Labor Force Participation, 1973-2009

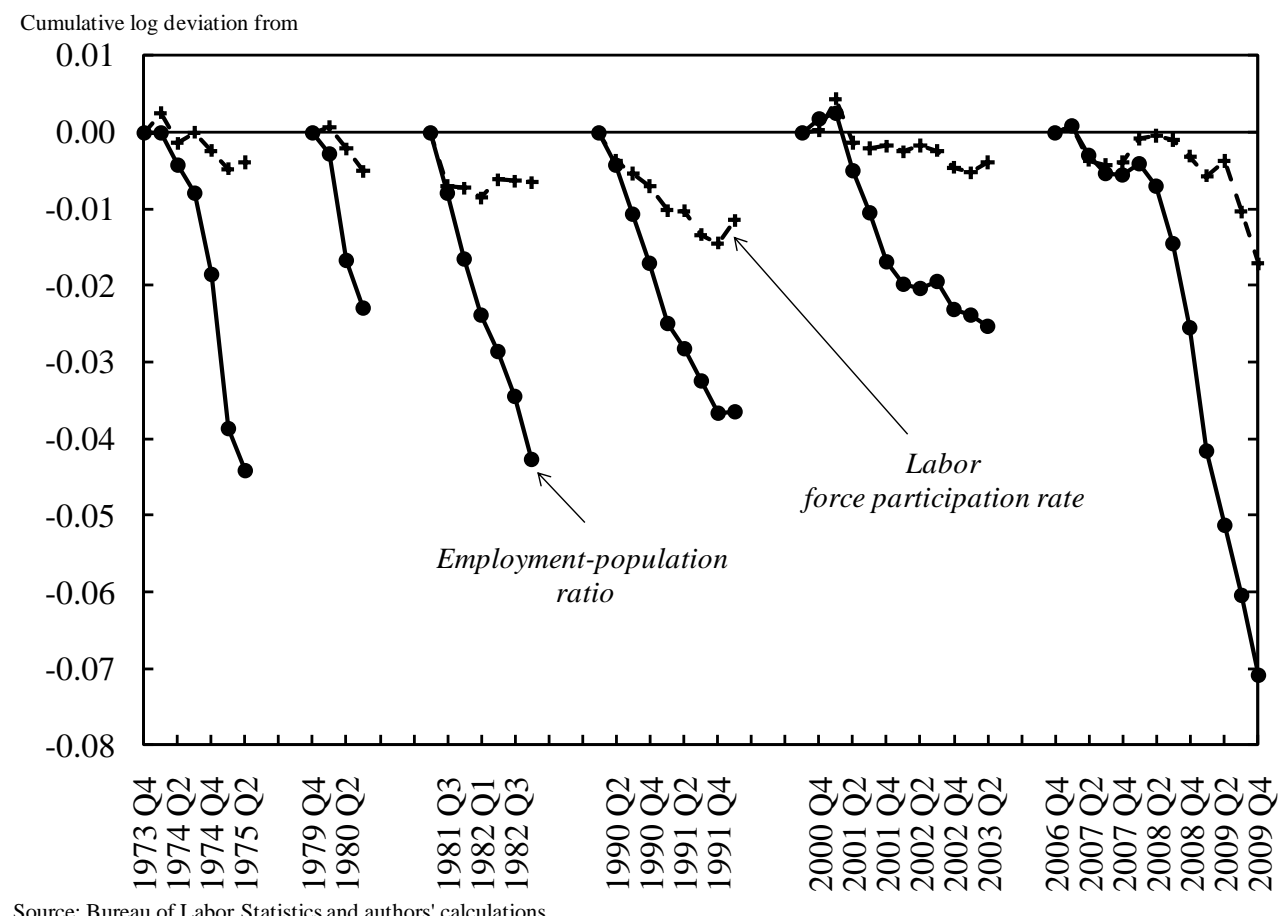


Figure 3. Okun's Law based on CBO output gap and NAIRU (1949-now)

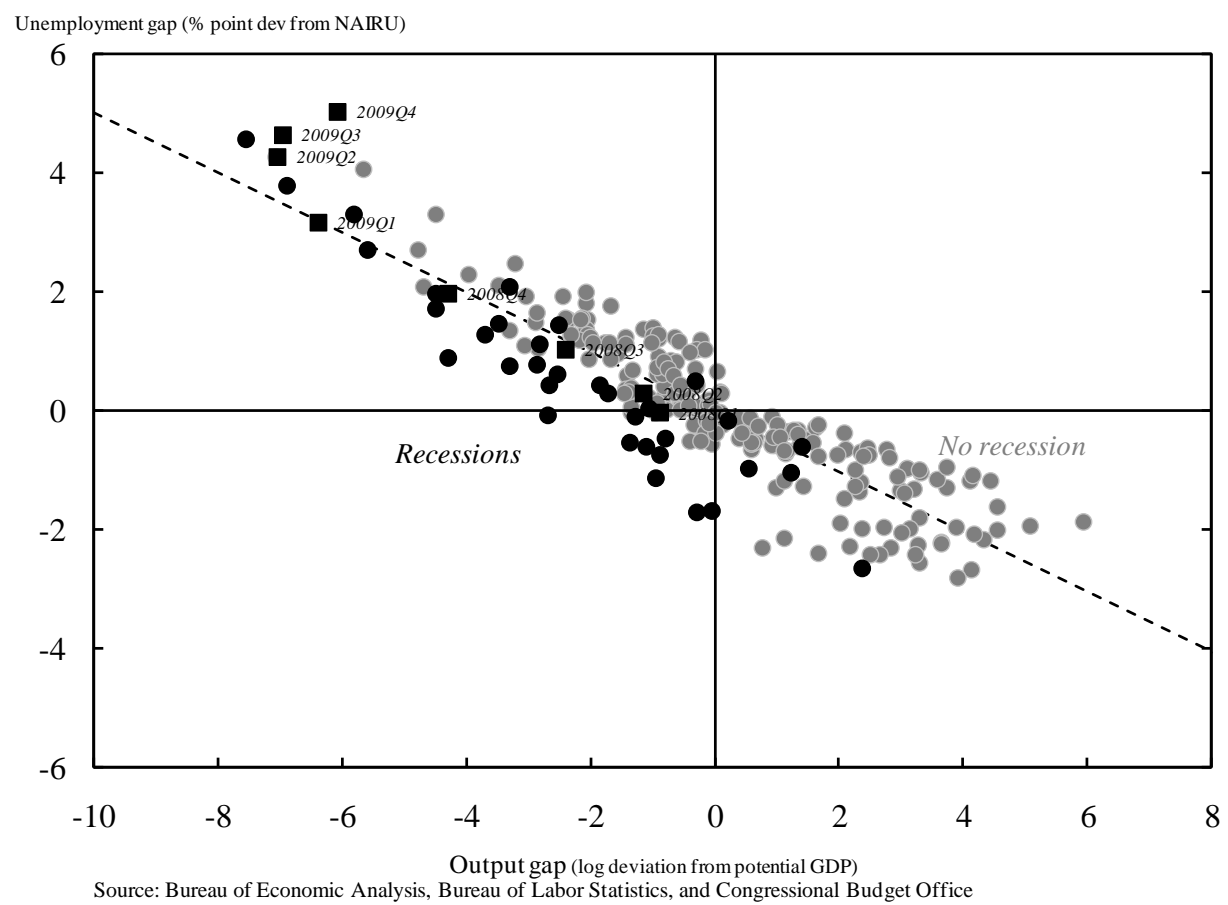

Figure 4. Hours vs. Bodies by Recession, 1973-2009

Cumulative log decline in employment and weekly hours per worker

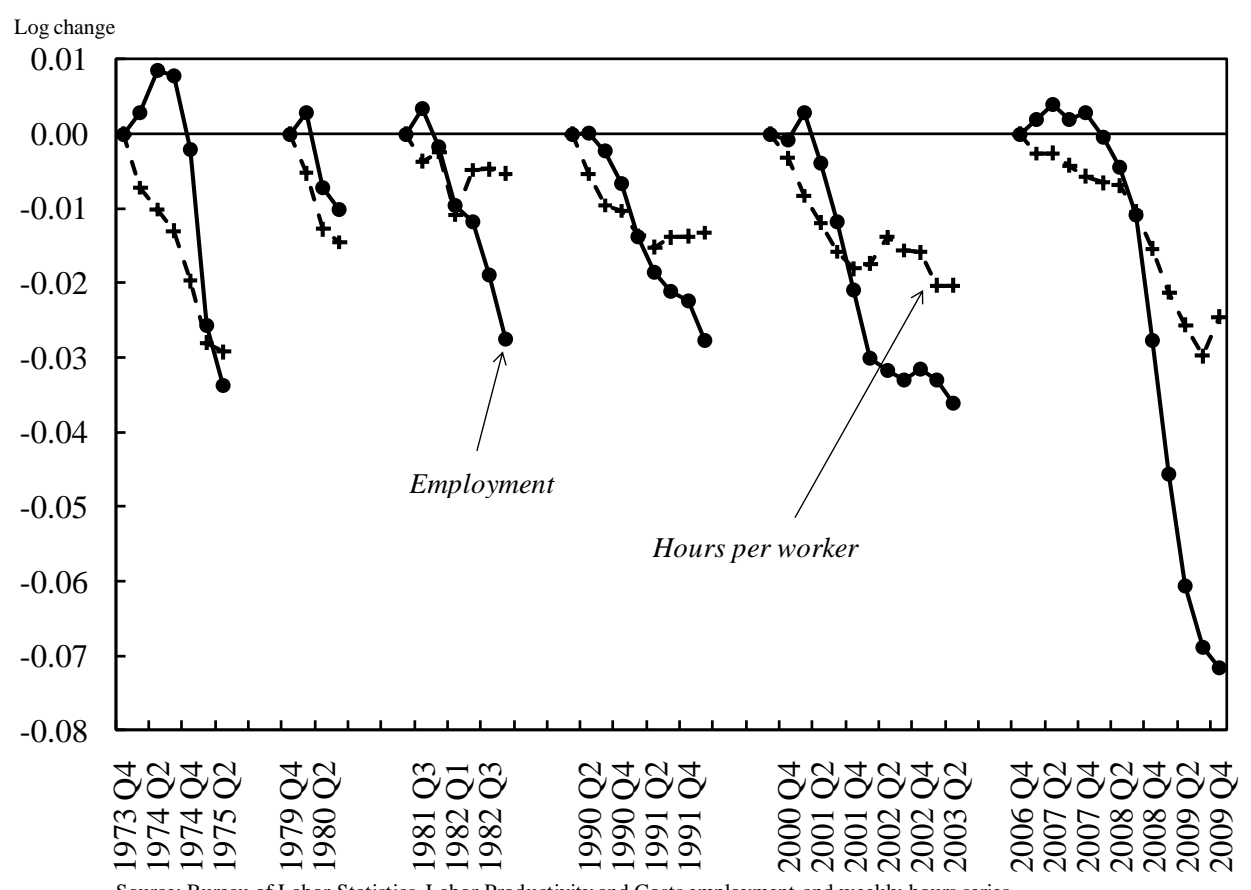


Figure 5. Age-Adjusted Unemployment Rate

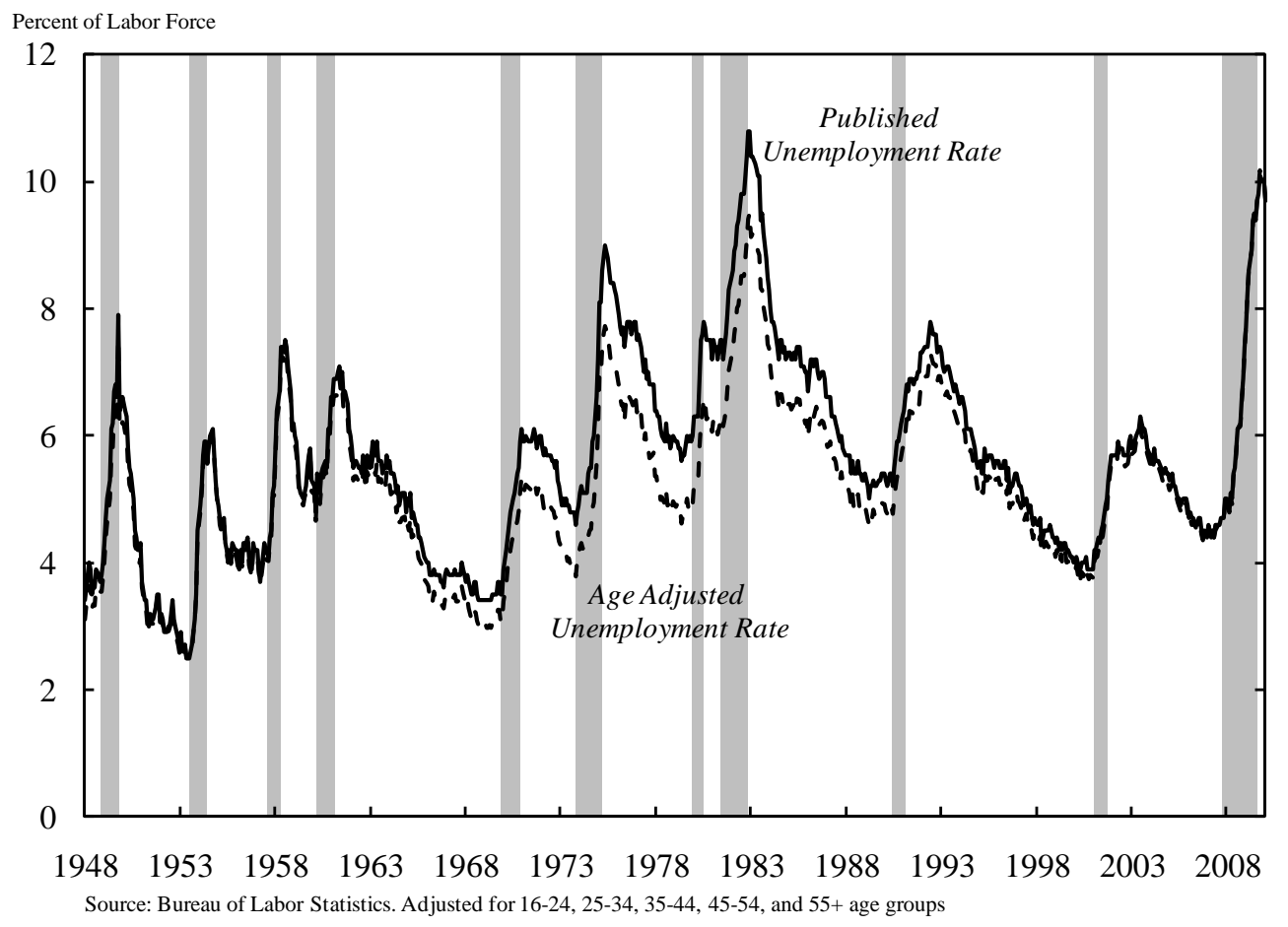

Figure 6. Unemployment Inflow and Outflow Rates

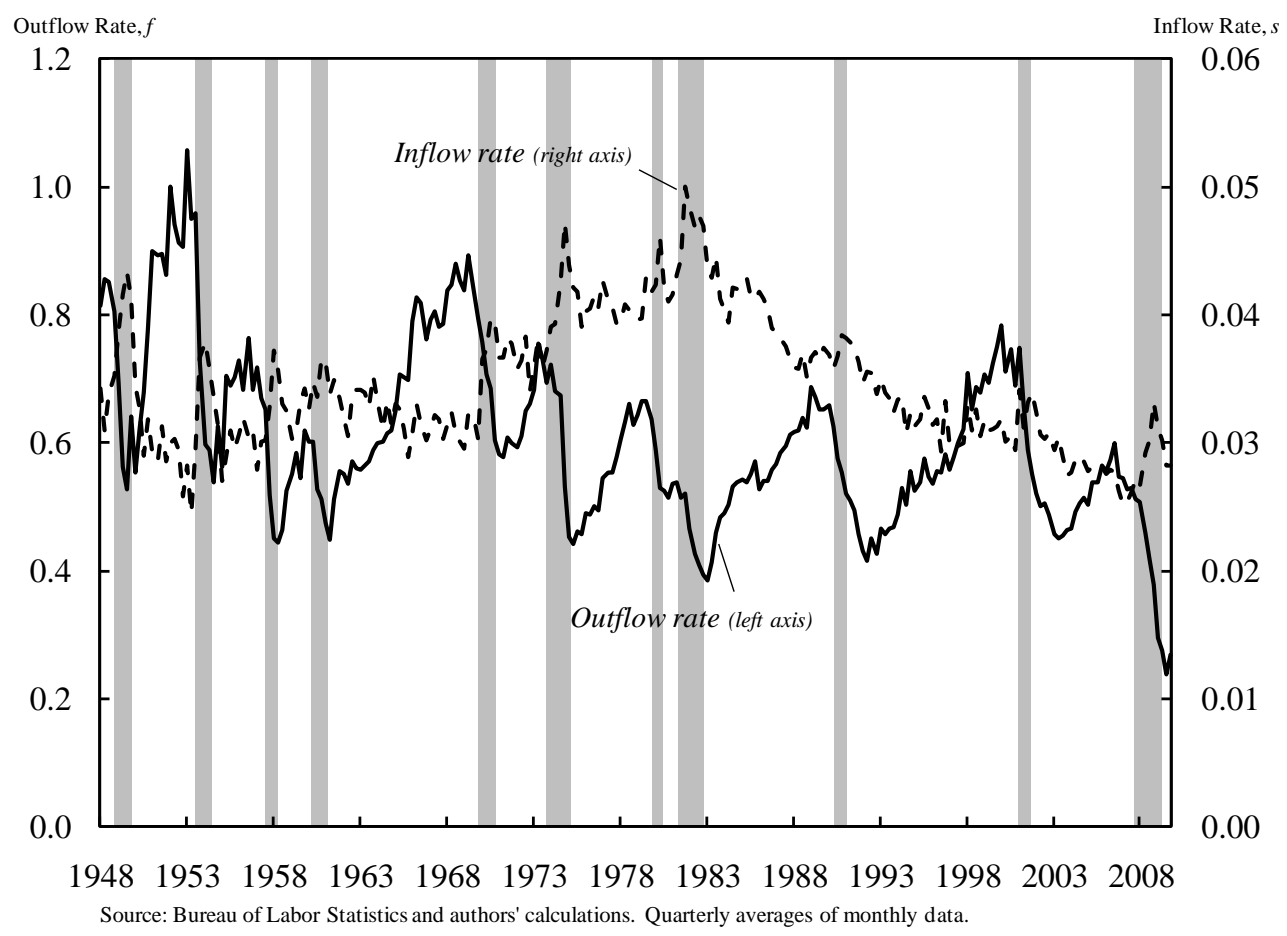


Figure 7. Contributions of Inflow and Outflow Rates by Recession, 1973-2009

Cumulative log change in hazards since the start of unemployment ramp up

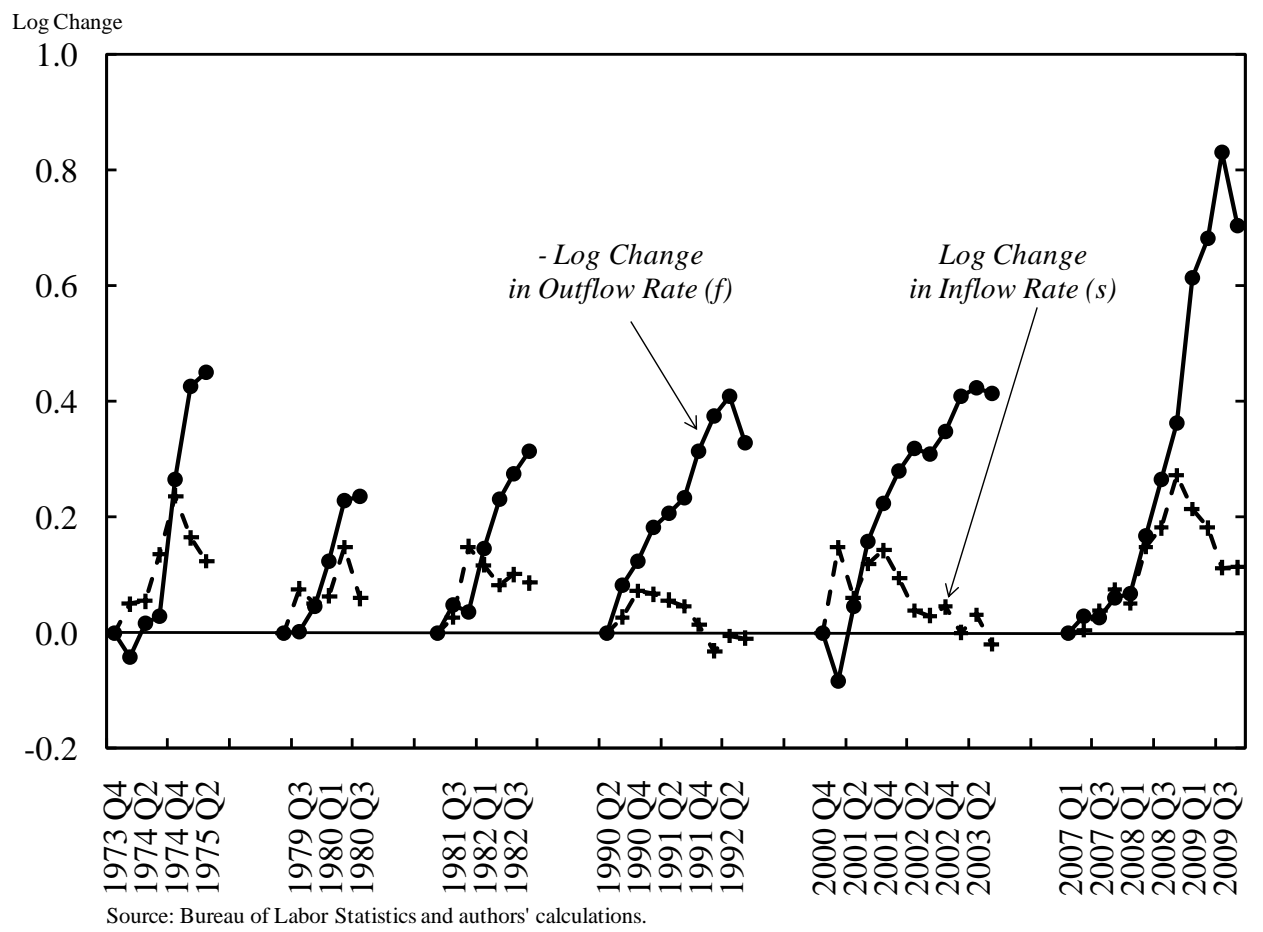




\section{Figure 8. Unemployment Flows by Demographic and Educational Groups}

12-month moving averages of seasonally adjusted monthly data

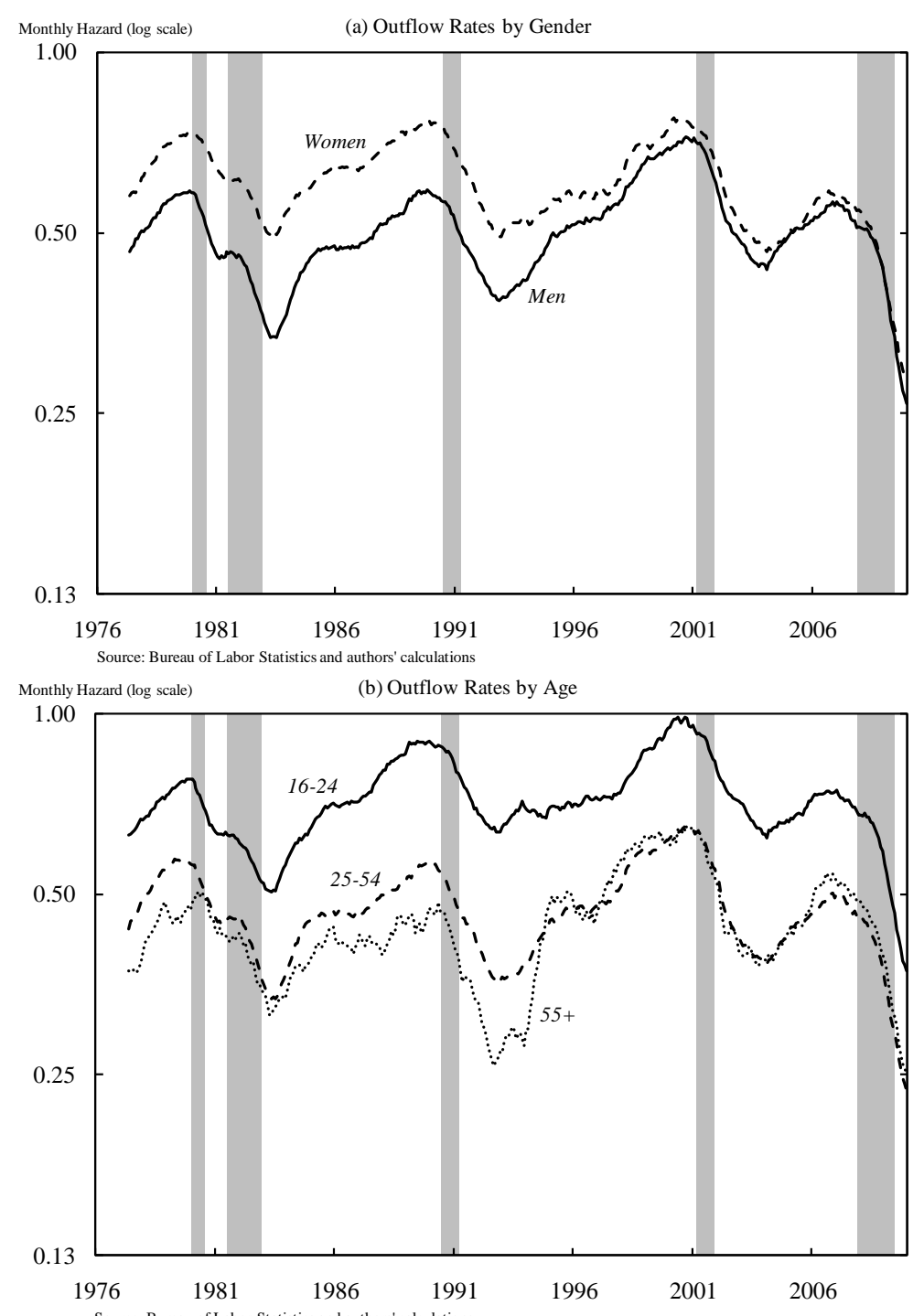

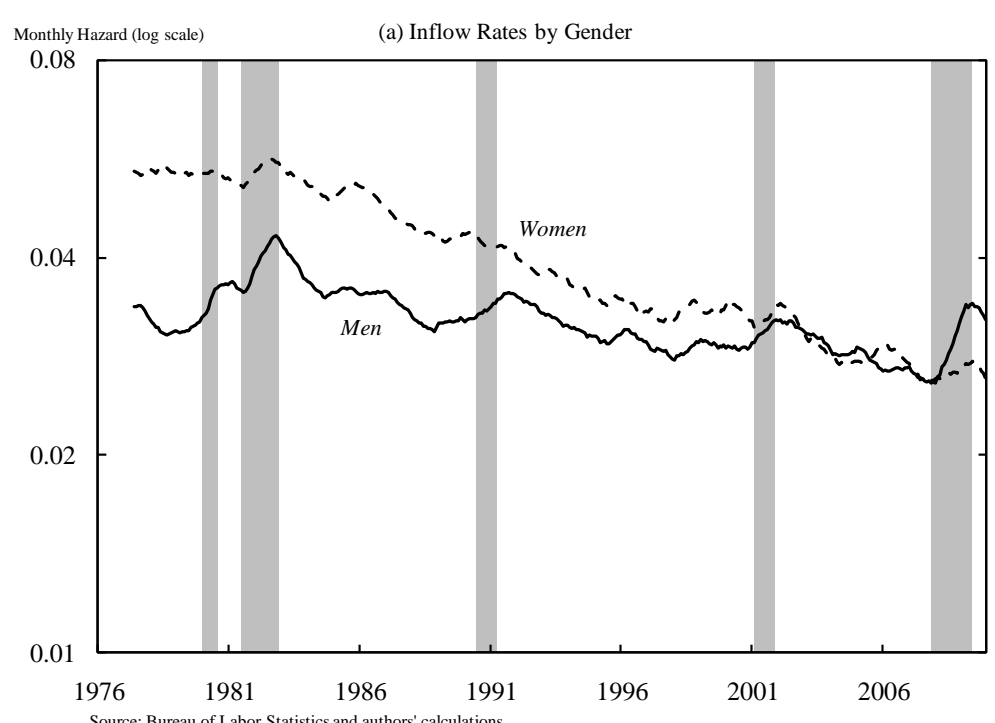

Source: Bureau of Labor Statistics and authors' calculations
(b) Inflow Rates by Age

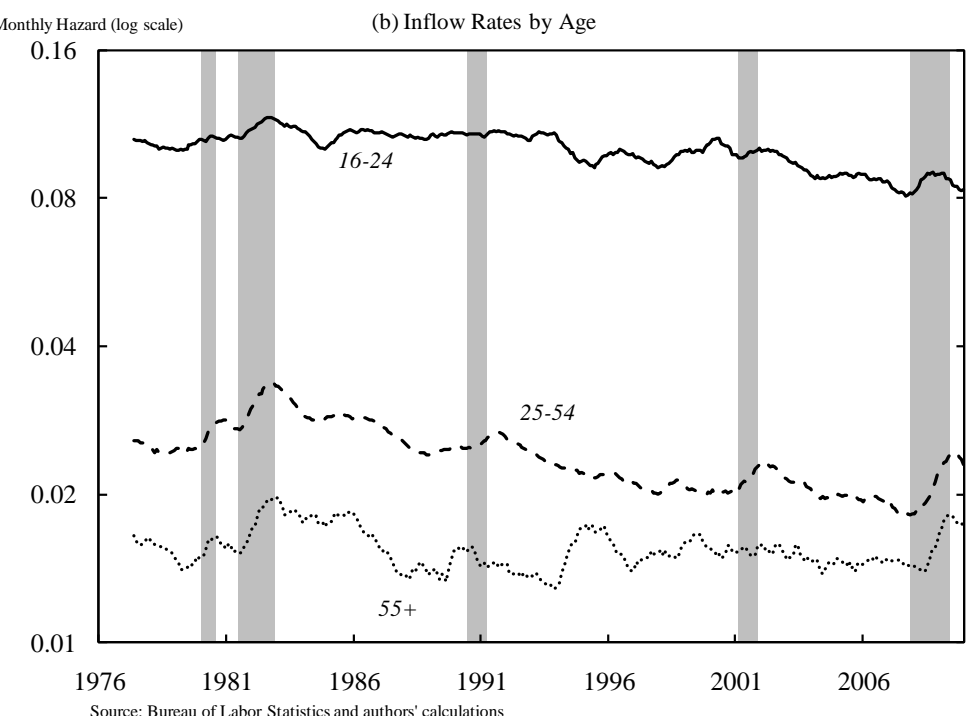




\section{Figure 8 - continued. Unemployment Flows by Demographic and Educational Groups}

12-month moving averages of seasonally adjusted monthly data
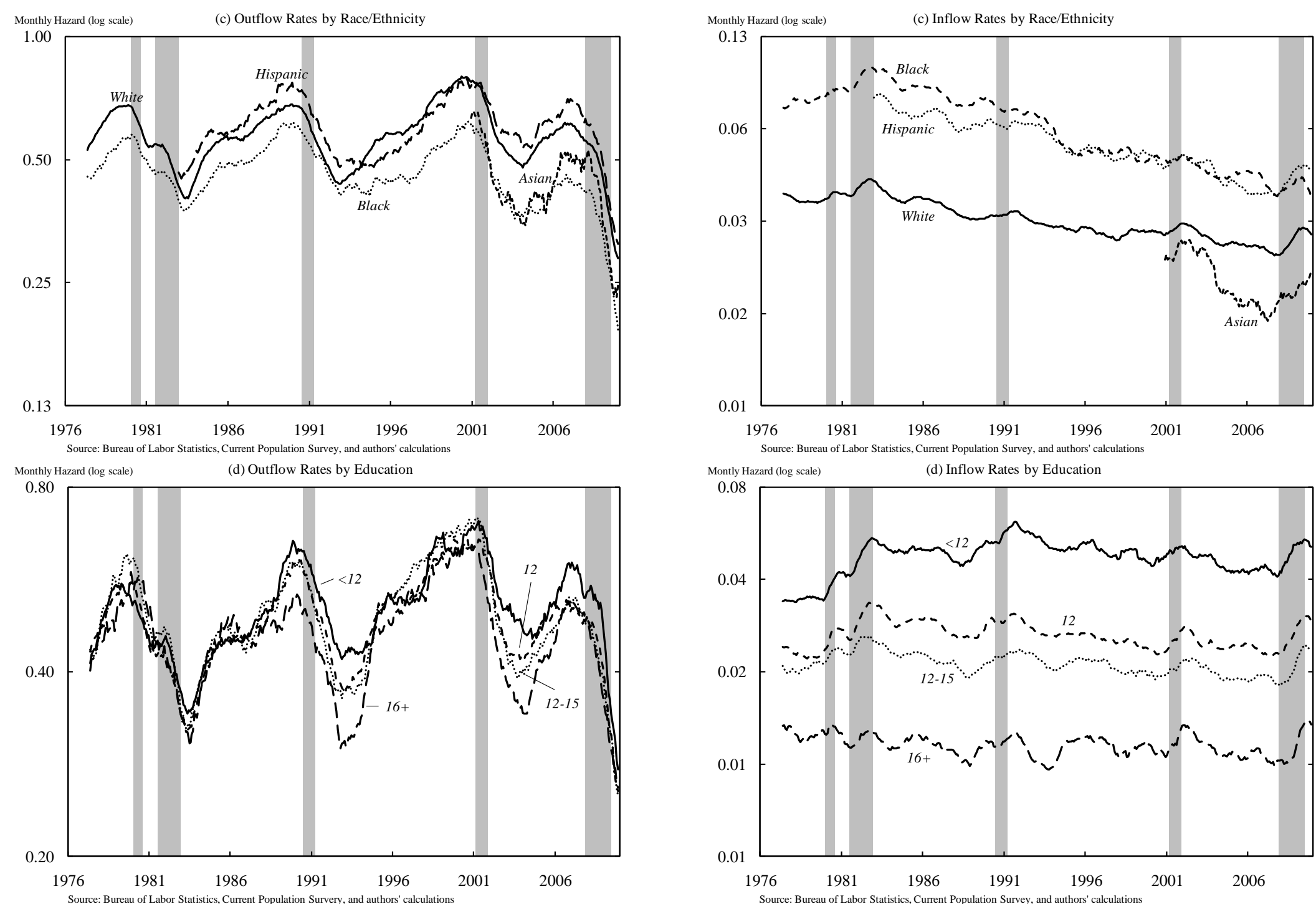
Figure 9. Unemployment Flows by Reason for Unemployment

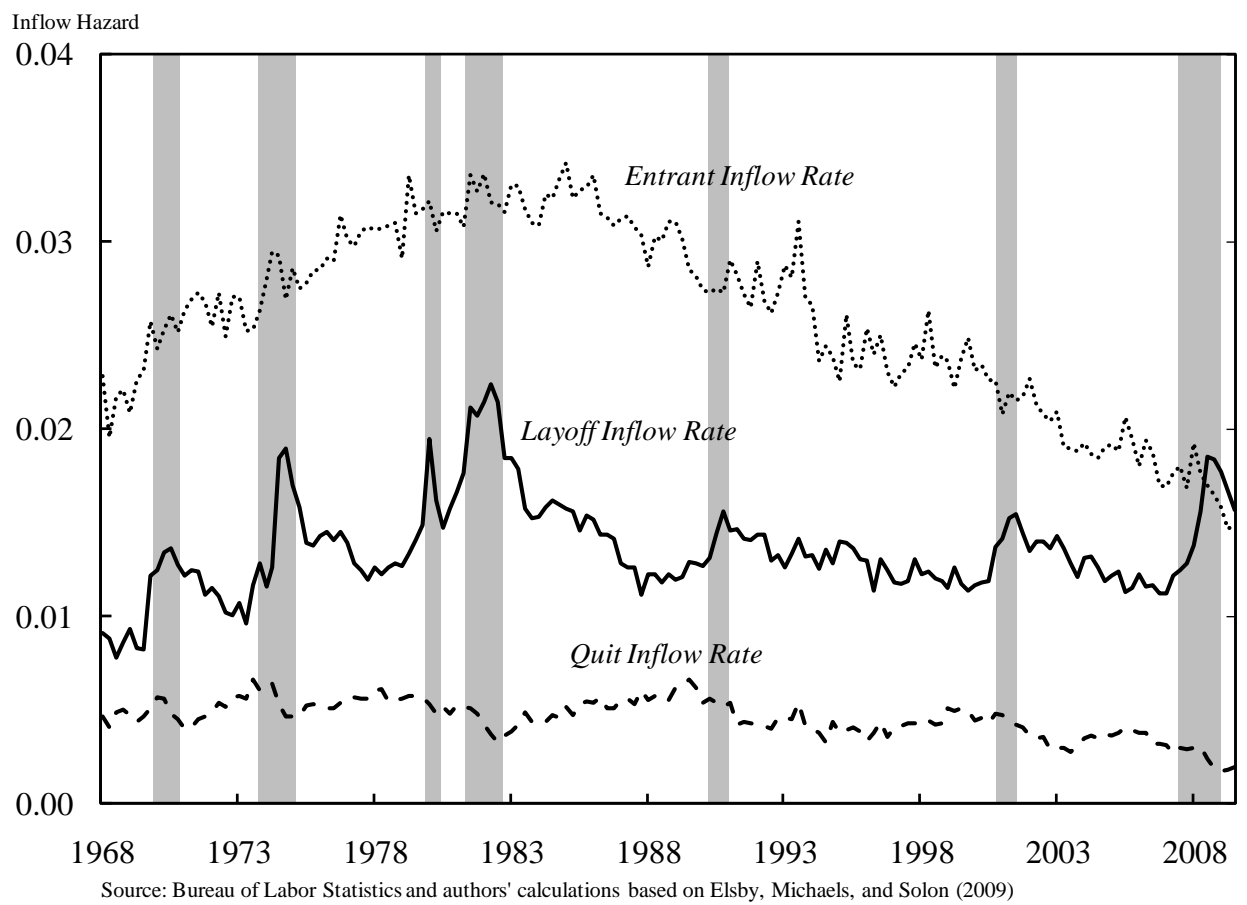

Figure 10. Separation vs. Employment to Unemployment Transition Rates

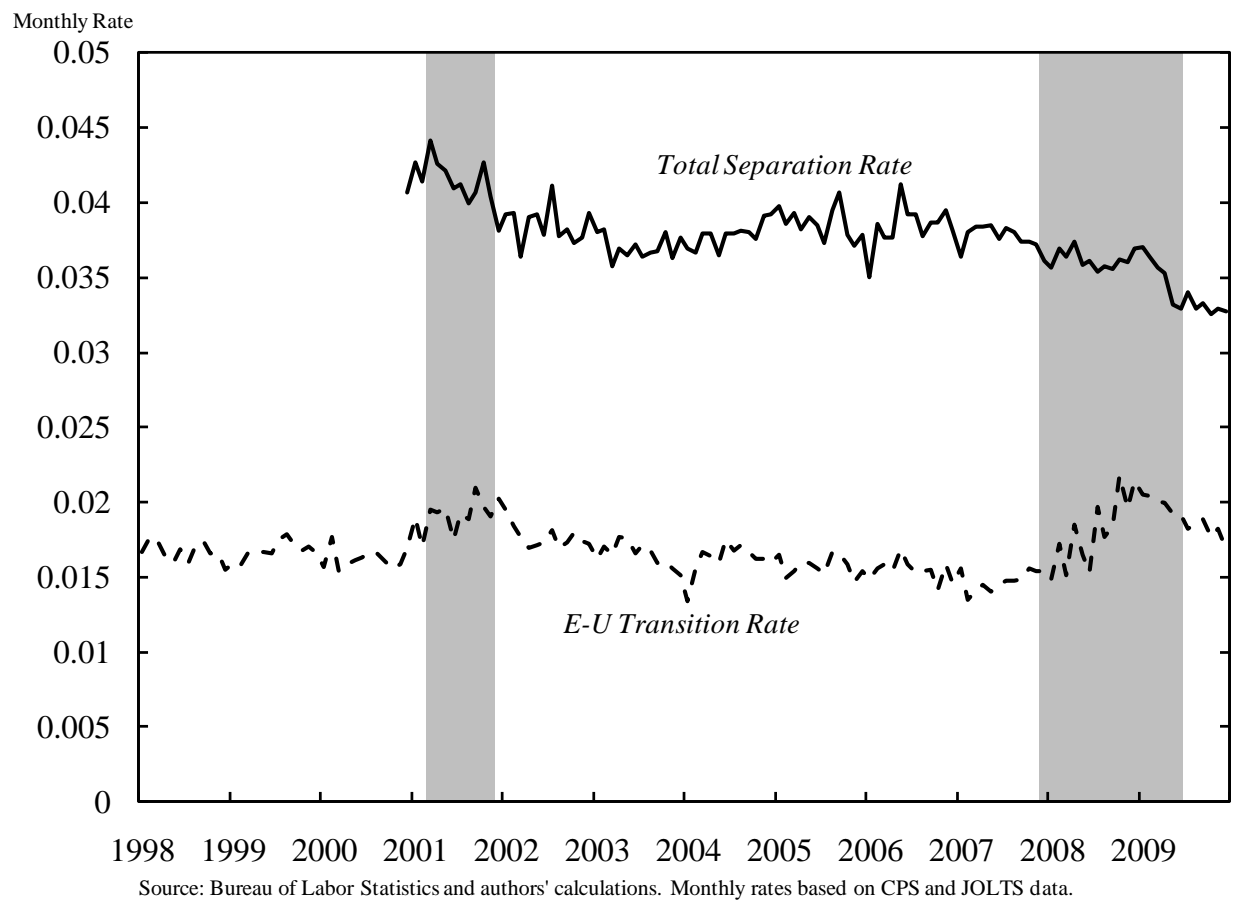


Figure 11. Separation and Unemployment Inflow Rates: Quits vs. Layoffs

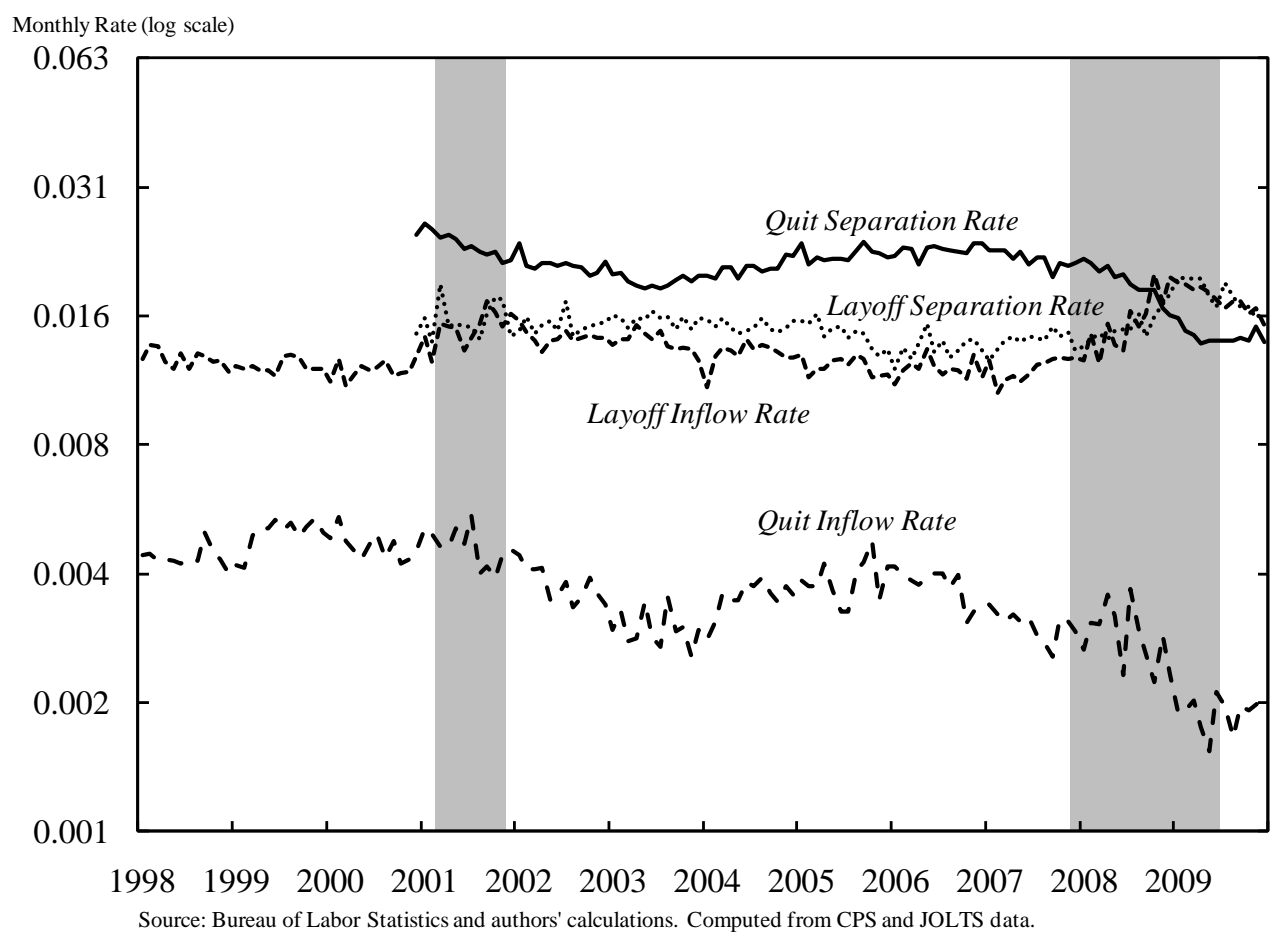

Figure 12. The Beveridge Curve

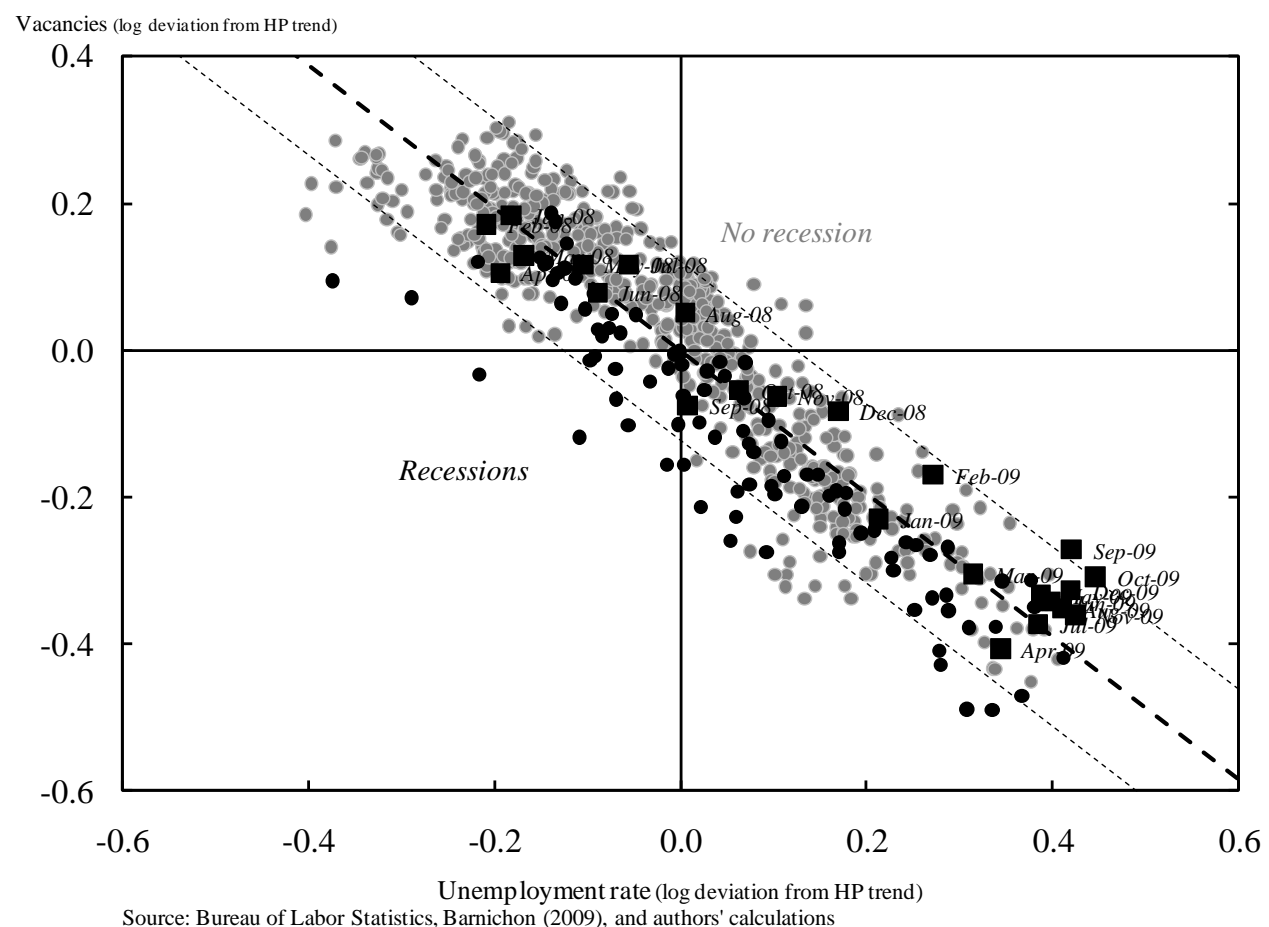


Figure 13. The Matching Function

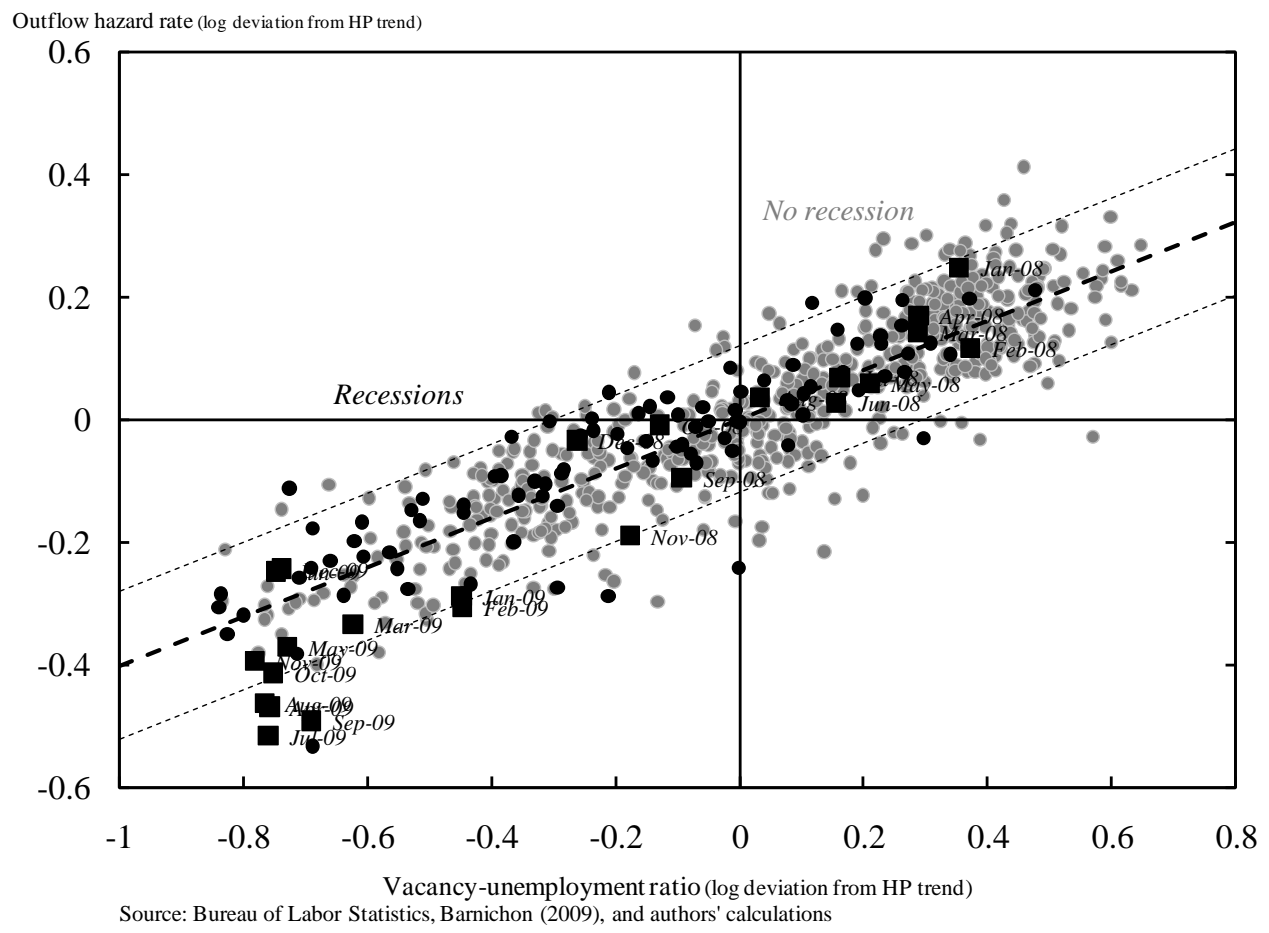

Figure 14. Unemployment Outflow Rates by Industry where Person was Employed at Start of Spell

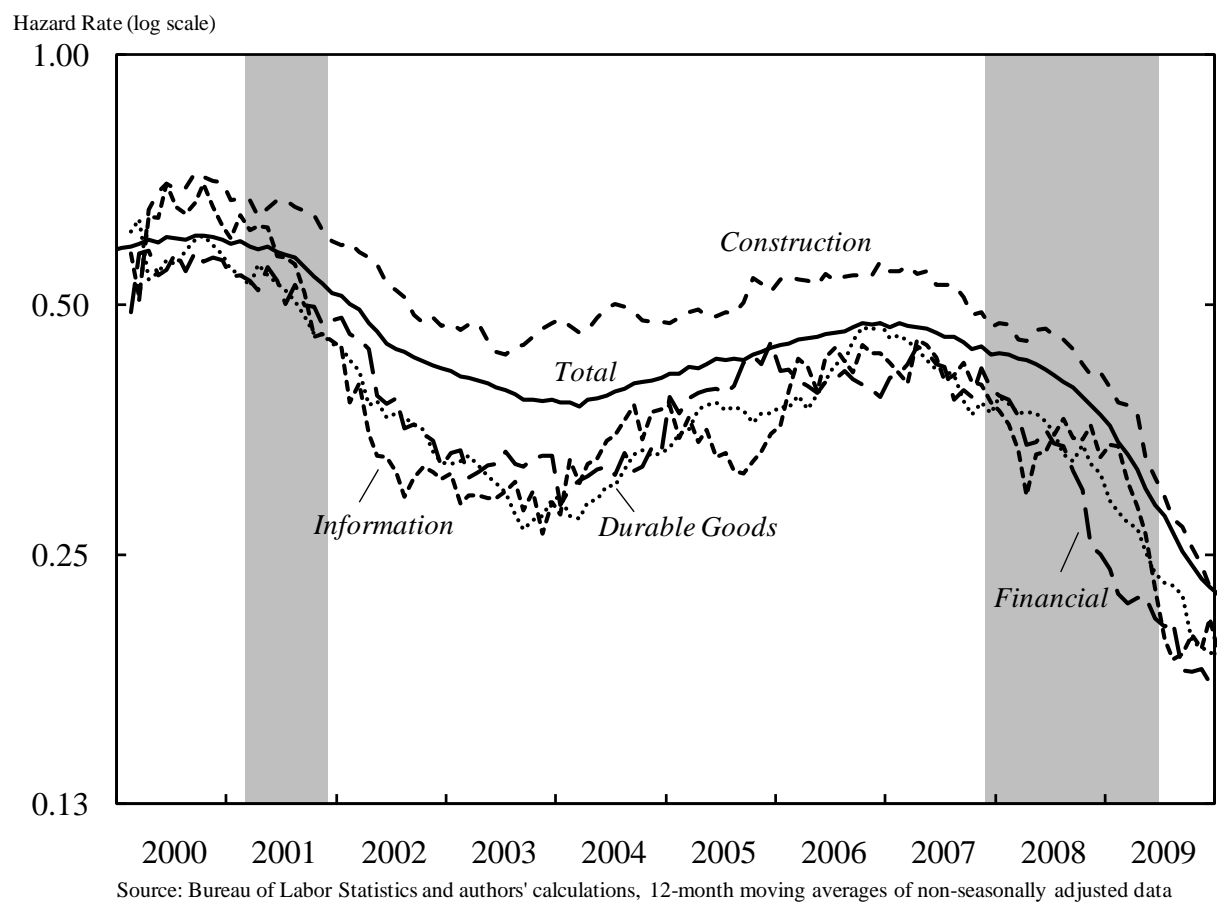


Figure 15. Unemployment Outflow Probabilities by Duration of Unemployment.

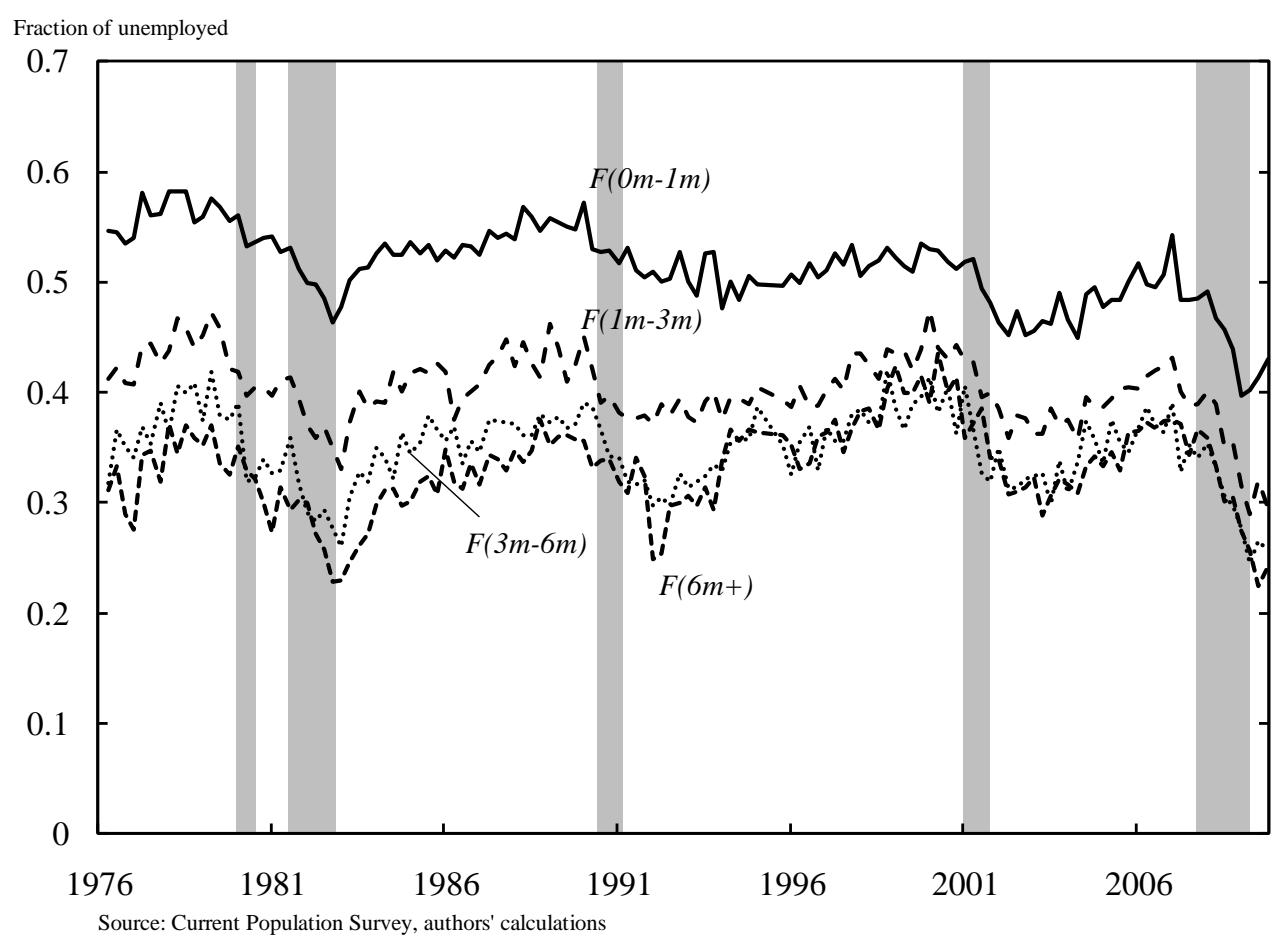

Figure 16. Long-term unemployment and the Outflow Rate in the Recovery

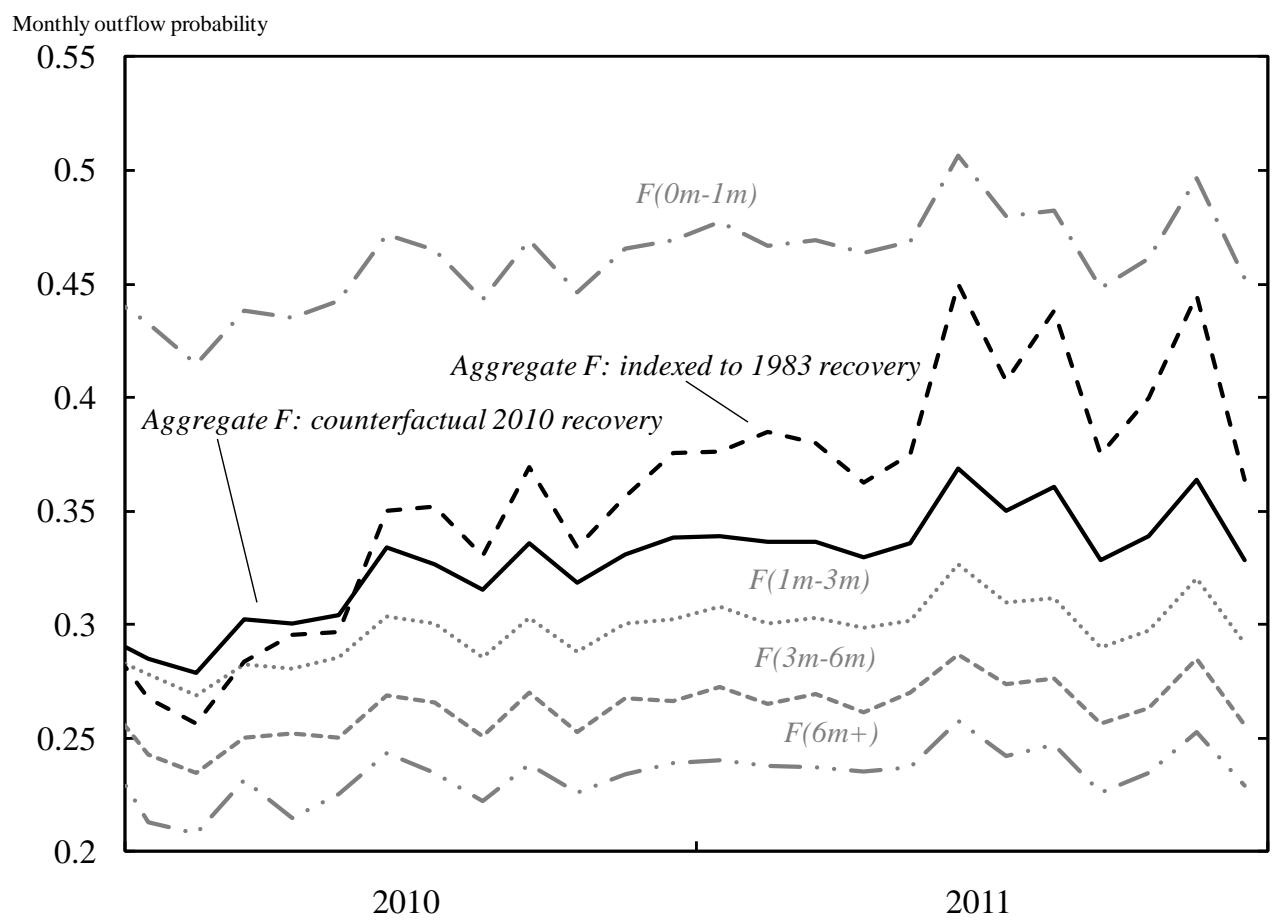

Note: Simulation of the recovery in the aggregate unemployment outflow rate in 2010/11 assuming that outflow rates by duration group recover at the same rate as witnessed in the 1983/4 recovery. For purposes of comparison, an index of the rebound in the aggregate outflow rate in the $1983 / 4$ recovery is plotted. 